\title{
COMPETITIVENESS, PRODUCTIVITY AND EXTERNALIZATION: FOOD VERSUS AUTOS IN CATALONIA
}

Pankaj Ghemawat 
The Public-Private Center is a Research Center based at IESE Business School. Its mission is to develop research that analyses the relationships between the private and public sectors primarily in the following areas: regulation and competition, innovation, regional economy and industrial politics and health economics.

Research results are disseminated through publications, conferences and colloquia. These activities are aimed to foster cooperation between the private sector and public administrations, as well as the exchange of ideas and initiatives.

The sponsors of the SP-SP Center are the following:

- Accenture

- Ajuntament de Barcelona

- Caixa Manresa

- Cambra Oficial de Comerç, Indústria i Navegació de Barcelona

- Consell de l'Audiovisual de Catalunya

- Departamento de Economía y Finanzas de la Generalitat de Catalunya

- Departamento de Innovación, Universidades y Empresa de la Generalitat de Catalunya

- Diputació de Barcelona

- Endesa

- Fundació AGBAR

- Garrigues

- Mediapro

- Microsoft

- Sanofi Aventis

- VidaCaixa

The contents of this publication reflect the conclusions and findings of the individual authors, and not the opinions of the Center's sponsors. 


\title{
COMPETITIVENESS, PRODUCTIVITY AND EXTERNALIZATION: FOOD VERSUS AUTOS IN CATALONIA*
}

\author{
Pankaj Ghemawat ${ }^{1}$
}

\begin{abstract}
This paper re-examines the innovation-productivity nexus on the basis of a paired comparison between Catalonia's food and auto sectors. The sectoral studies expose a set of productivity enhancement mechanisms that do not involve innovation in the sense of anything new to the world, that are grouped under the rubric of renovation and comprise:
\end{abstract}

- Reaching efficient scale

- Rectifying (other) obvious internal deficiencies

- Replicating or imitating innovations, techniques, etc., developed by others

- Replacement of inefficient incumbents by more efficient entrants

- Redeployment of resources across sectors

The paper also discusses the implications of this broader perspective for industrial policy, and for internationalization.

Keywords: Productivity, Innovation, Industrial Policy, Internationalization, Globalization, Strategy.

\begin{abstract}
* ACKNOWLEDGEMENTS: I would like to express my gratitude to Silvia Bellezza and Victor Cazorla for their work drafting the initial reports on the Catalan food and auto sectors respectively, to Carlos Llano and Francisco Requena for providing data on Spanish interregional trade flows for the two sectors, to Bruno Cassiman and Elena Golovko for obliging with numerous calculations for the food and auto subsamples of their sample of Catalan firms, to Bruno Cassiman, Xavier Vives and other participants in a workshop at IESE Business School in Barcelona at which an earlier version of this paper was presented, and to Jordi Ollé for help in preparing this paper for publication.
\end{abstract}

\footnotetext{
${ }^{1}$ Professor Strategic Management, IESE
} 


\section{COMPETITIVENESS, PRODUCTIVITY AND EXTERNALIZATION: FOOD VERSUS AUTOS IN CATALONIA*}

\section{Introduction}

The previous chapter (Ghemawat, Llano and Requena) highlighted the importance of taking a geographically coherent perspective on regional competitiveness by looking at interregional as well as international linkages. This chapter builds on this insight, but pushes the analysis down to the sectoral level by focusing on two salient manufacturing sectors in Catalonia, food and beverages (henceforth mostly referred to as "food") and transport equipment (henceforth mostly referred to as "autos"). Focus permits a more micro examination of the antecedents and consequences of productivity growth.

While there is a vast literature on this broad topic, at a very basic level, most of it seems to conform to the "Standard Model" depicted in Figure 1: a representation in which innovation drives productivity growth (link 1), and success in international markets, usually measured by exports or net trade surpluses, is a key outcome (link 2).

\section{Figure 1}

Antecedents and Consequences of Productivity Growth: the Standard Model

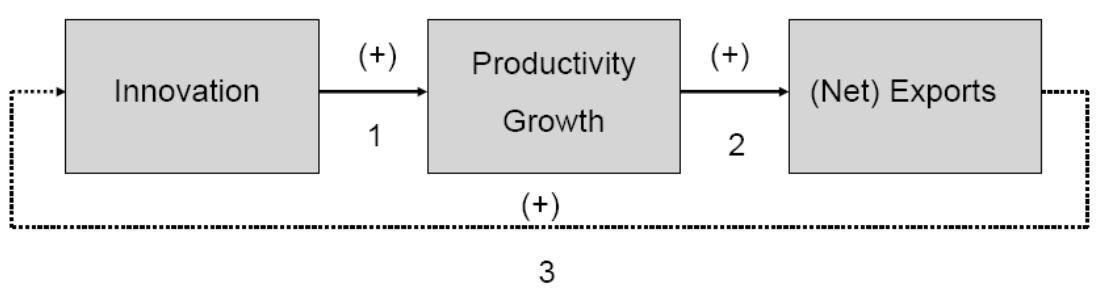

Food and autos were selected as the sectors on which to focus in this micro re-examination of the Standard Model on the basis of differences in innovation-intensity: food is categorized as low tech in most such industry classification schemes (e.g., the OECD's). and autos as medium tech. ${ }^{1}$ In other words, the two sectors were selected to provide a contrast in terms of the first box in the Standard Model.

\footnotetext{
${ }^{1}$ As part of this attempt at stratification by technological intensity, a parallel treatment of biotechnology as a hightech sector (actually, technology) to complement low-tech food and medium-tech autos was planned originally. But given the very distinct, much more science-focused issues that biotech raises, the study of biotechnology in Catalonia was hived off into a separate effort by Nuria Mas and Javier Botella.
} 
Upon further examination, the two sectors also appeared to provide interesting contrasts in regard to the other boxes in the Standard Model. In terms of the second box, labor productivity in the food sector in Catalonia has grown fairly fast - at an annual rate of 2.4\% over 1995-2003 - and is slightly higher than the average for the EU-25. Autos presents the opposite profile: Catalonia's labor productivity has grown much more slowly - at 0.5\% over 1995-2003 - and is somewhat lower than the average for the EU-25. And in terms of the third box, Catalonia has run a chronic international trade deficit in food, but historically posted large trade surpluses in autos, which was the only manufacturing sector to make a positive contribution to Catalonia's international trade balance over 1995-2006. (Even though the international trade balance in autos started deteriorating in the early 2000s and swung into the negative in 2004, Catalonia's international deficit in this sector was still, as of 2006, much smaller than in food.)

Food and autos turn out not only to present contrasts in terms of each of the three boxes but also seem to contradict the relationships predicted by the Standard Model between the (adjacent) boxes. Puzzle 1 concerns link 1: why should labor productivity in food, which is a low tech sector, have grown nearly five times as fast as in autos, which is a medium tech sector? And Puzzle 2 concerns link 2: given that labor productivity has grown much faster in food, we might expect it to exhibit a better (or at least improving) trade position than autos, but the reverse appears to be true. It is also of interest to note that if one focused on the reducedform relationship between innovation-intensity and trade performance and failed to consider productivity, one would probably miss out on both these issues and conclude, reassuringly, that Catalonia is doing better in the medium tech sector than in the lower tech one (often subject to hand-waving about commoditized competition from lower-cost countries).

Puzzle 2 seems, given the previous chapter, to admit of a relatively easy resolution: focus on international plus interregional trade balances rather than just international trade balances. Once one does so, food, the high-productivity (growth) sector, is also the one revealed to have a better trade performance, in line with the prediction for link 2 in the Standard Model. Figures $2 \mathrm{a}$ and $2 \mathrm{~b}$ make the same point more broadly by relating changes in revealed advantage indicated by the two types of trade measures to productivity growth. Note that the correlation between productivity growth and changes in advantage triples when one takes interregional trade into account (and R-squared jumps from 5\% to more than 50\%). One way of summarizing the data is that with productivity growth rates of less than 1.5\% (close to the average for all of Catalan manufacturing), sectors' revealed advantages tended not to increase, whereas with growth rates greater than $1.5 \%$, they tended not to decrease.

Figure $2 \mathrm{~b}$ is also of relevance to concerns that Catalonia is somehow focusing on the wrong sectors. The specific concern as articulated by Jaumandreu is that Catalonia is gaining external advantages in low-tech rather than high-tech sectors. An alternate hypothesis that does not require systematic mistakes across firms is that the Catalan economy is simply specializing in sectors that offer it the highest productivity growth rates, as depicted in Figure 2b. Of course, the lack of coincidence between these sectors and R\&D-intensity - Puzzle 1 - remains to be explained, and is the principal focus of this chapter. 


\section{Figure 2a}

Revealed international advantages vs. productivity growth

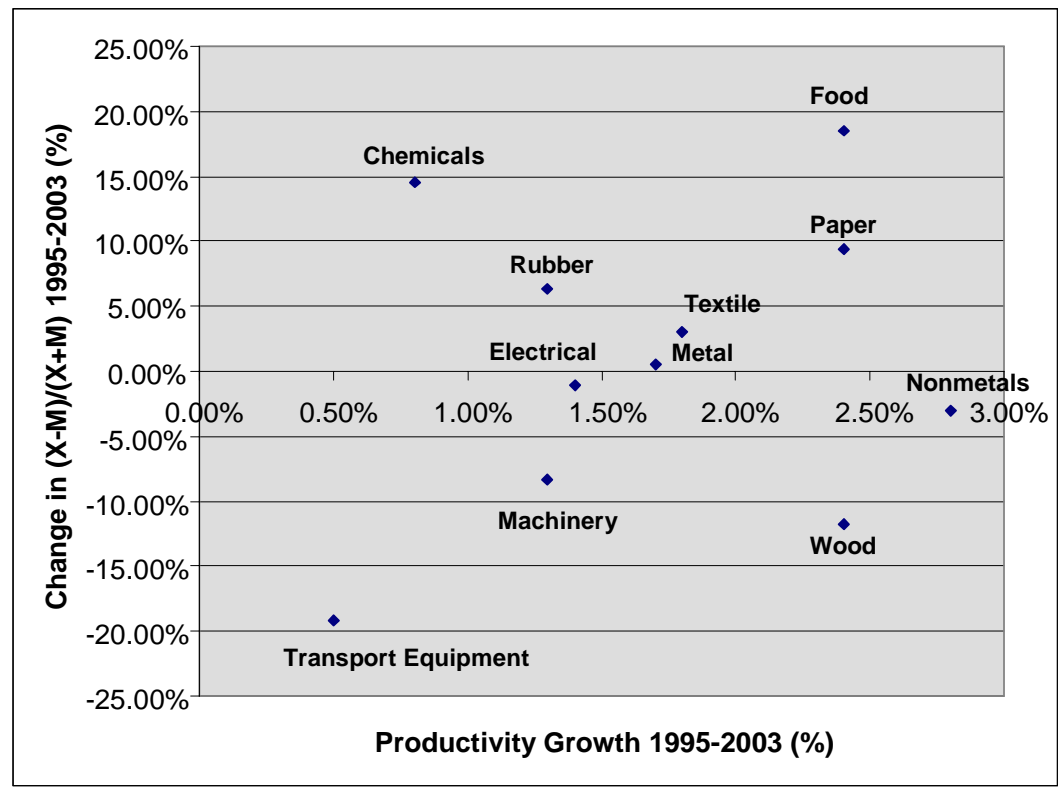

\section{Figure $2 b$}

Revealed international and interregional advantages vs. productivity growth

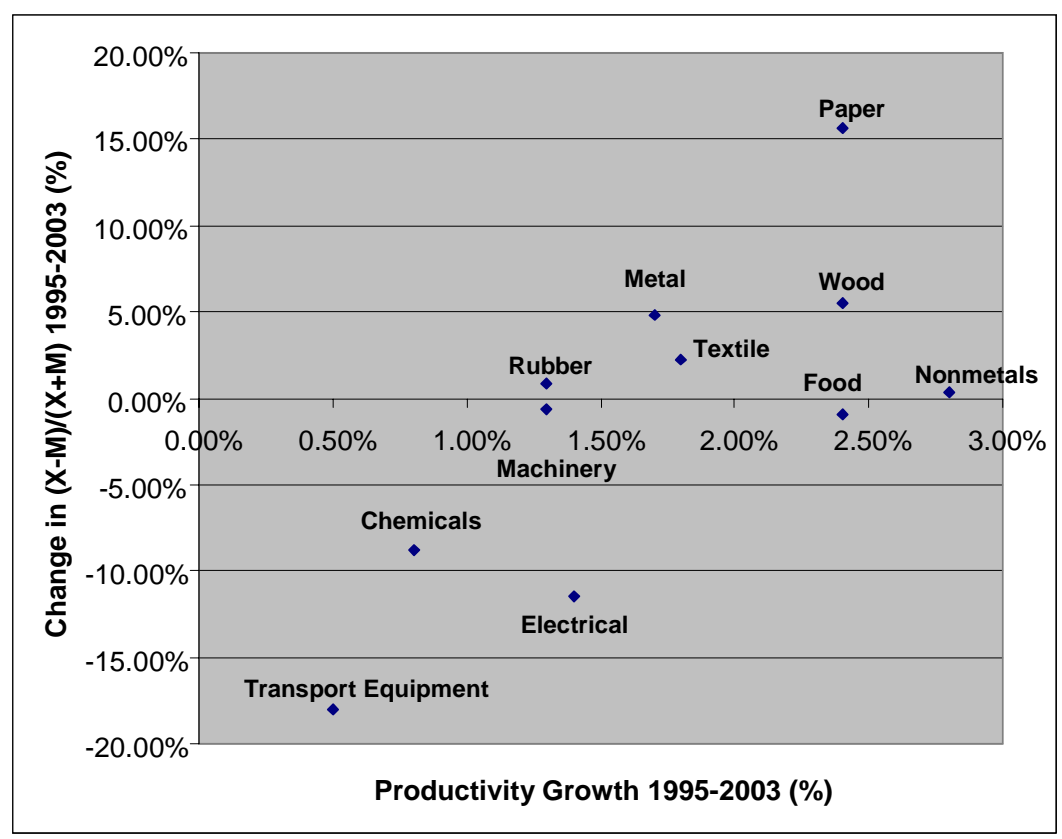

How did food, a low tech sector, grow productivity several times as fast as autos, a medium tech sector? The answer that emerges from a paired comparison of the two sectors is that link 1 in the Standard Model, between innovation and productivity growth, is an inadequate way of thinking about the antecedents of the latter. Specifically, the sectoral studies expose a set of other significant productivity enhancement mechanisms that do not involve innovation in the sense of anything new to the world, and that I group under the rubric of renovation: 
- Reaching efficient scale

- Rectifying (other) obvious internal deficiencies

- Replicating or imitating innovations, techniques, etc., developed by others

- Replacement of inefficient incumbents by more efficient entrants

- Redeployment of resources across sectors

All the mechanisms listed so far focus on the supply side, but there is substantial evidence of important demand-side influences on innovation, etc. These too must be considered in taking a broad view of how to grow productivity.

Section 2 begins by looking at the food and beverages sector, and Section 3 extends the coverage to the auto sector. Section 4 discusses the implications of this broadened conception of productivity, Section 5 focuses on internationalization as a vehicle for productivity growth - because opening up to the outside can help drive productivity growth in a number of different ways - and Section 6 concludes.

These ambitious objectives and space constraints preclude provision of thick, systematic or even entirely parallel descriptions of the two sectors - especially since each aggregates across very diverse industries which are the principal loci of competition. Thus, while food and beverages is generally a low R\&D - intensity sector in which the scope of many of the largest companies is regional rather than global, within it, ice cream is a high R\&D-intensity industry in which the leading competitors have global scope - and spend more than 10\% of sales on R\&D! Picking up on such heterogeneity is beyond the scope of this sectoral analysis, which therefore takes a more aggregated perspective and refers to a number of other, more detailed sources as appropriate. For summaries of much of the descriptive data, see the sectoral profiles prepared under my direction by IESE Business School MBAs Silvia Bellezza and Victor Cazorla of, respectively, food and beverages and autos; these are available from the SP-SP website/Foment and will simply be relied on without further citation here. A number of other sources of information or assistance - other chapters of this book, private communications from their authors, and other studies - are also employed and will be cited as appropriate. The treatment here, instead of purporting to hold up a mirror to the two sectors, offers up broad - although in some respects, overly aggregated - interpretations of their evolution and future prospects, framed in terms of the overarching concern with productivity growth. It should be read more as an essay that makes points relevant to the current public policy debate about productivity growth that are grounded in the cases of two Catalan sectors.

Yet interregional trade flows are comparable - to within a factor of two - to international flows in the two Catalan sectors studied: twice as large in food and beverages and half as large in automotive. And, as the former illustrates, ignoring interregional flows can lead to a fundamental - and costly - misdiagnosis of external competitiveness.

\section{The Food and Beverage Sector}

Food and beverages is a traditional sector: thus, Miquel Viladrich's (1930) painting in the Generalitat Building in Barcelona depicts a portfolio of Catalan specialties in this regard. The sector is not growing very quickly, especially in developed parts of the world, and is characterized by the OECD as low tech. In addition, Catalonia regularly reports an international trade deficit in food and beverages. For all these reasons, it is not uncommon to dismiss food 
and beverages as of limited developmental interest: thus, a recent study uses a BCG-style growth/relative position matrix to characterize it as a "cash cow" to be milked rather than as a "star" on which Catalonia should concentrate in the long run (Torrens and Raluy, 2008). This would almost certainly be the wrong conclusion.

It is useful to begin with the reminder that, if one looks at interregional as well as international trade, Catalonia looks very competitive rather than uncompetitive externally in food and beverages. Interregional trade, in which Catalonia posts a large external surplus, is significantly greater than international trade in this sector, reflecting the high border effect estimated for this sector in Chapter 4. One might add that a regional perspective is indicated at the international as well as the intranational level: nearly four-fifths of Catalonia's food and beverage international exports and two-thirds of its international imports are accounted for by trading partners within the EU. The key trading relationships, both international and intranational, seem to be underpinned by various cultural, administrative, geographic and economic affinities.

This strong external performance, overall, is underpinned by a labor productivity growth rate of 2.4\% over 1995-2003, which helped push Catalonia's productivity in this sector above the average for the EU-25 as well as for the rest of Spain (see Jaumandreu, 2008, Table 3). This rate of growth also compares very favorably with the $0.9 \%$ growth rate posted by the EU-15 over 1995-2002, let alone the $-5.2 \%$ rate recorded by the food and beverage sector in the United States. ${ }^{2}$ In Cassiman and Golovko's sample, average labor productivity in food and beverages increased by 37\% in real terms between 1990-1999 and 2000-2006. The increase was not accomplished through reductions in aggregate employment, which actually grew at a $0.5 \%$ rate between 1993 and 2006. Nor does it reflect increased pricing power: the sector's return on sales has stagnated around 3\% in the last decade - slightly lower than the return for the average Catalan firm, which was closer to $4 \%$.

\section{R\&D-Based Innovation?}

It seems clear that the sector's above-average productivity growth - tied for second place among the two-digit NACE sectors analyzed in the previous section - cannot easily be ascribed to above-average rates of innovation, particularly R\&D-based innovation. An average R\&D-tosales ratio of less than $1 \%$, in line with perceptions that this is a low tech sector, is one indication. Attempts to "remedy" this state of affairs with public support are not regarded as having achieved the desired results. One concrete example is provided by a study for 20002002 that compared patenting activity by firms which received public financing for innovation in Catalonia, Belgium and Denmark: see Figure 3. ${ }^{3}$ Another comes from a study of the R\&D carried out in food and beverages by 69 Catalan entities - both firms and public/nonprofit institutions such as universities and research centers - which concluded that, apart from a few islands of innovation in multinational companies (e.g., Danone, Nestlé, Unilever) and large Catalan/Spanish companies (e.g., Agrolimen), the level of R\&D-based innovation in Catalonia is very low.

\footnotetext{
${ }^{2}$ McKinsey \& Company (2004).

3 "Innovation in Catalonia" (2006).
} 


\section{Figure 3}

Public financing for innovation

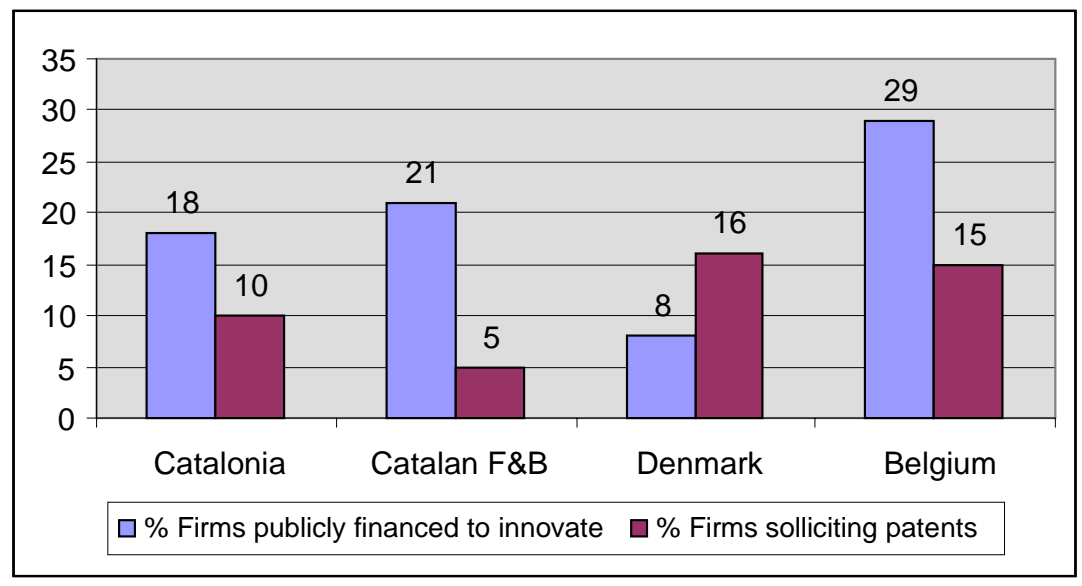

Source: "Innovation in Catalonia", CIDEM, Study Collection, 2006, page 173.

Danone provides a particularly striking example of R\&D-based innovation: see Box A. That said, it is a striking example precisely because it is exceptional: its strategy is much more R\&Dfocused than most other MNCs', let alone the strategies of the few large local companies that routinely engage in R\&D-based product innovation. And even Danone's R\&D budget amounts to just $1.2 \%$ of sales - low by the average standards in many other sectors, e.g., autos.

\section{Box A}

\section{Innovation at Danone}

Groupe Danone's mission is "Bringing health through food and beverages to the greatest number of people...”. The company places a heavy emphasis on new product development and validation in pursuing this mission, and describes its research and innovation initiatives as spanning five broad areas: ferments and probiotics, nutrition and physiology, health benefit claims, formulation engineering and sensorial analysis, and the analysis of consumer behavior. In 2006, Danone had 900 research staff around the world, reported 200 ongoing scientific collaborations, and launched nearly 1000 new products worldwide.

Jérôme Boesch, CEO of Danone España, distinguishes among three different degrees of innovation within F\&B:

"Me-Too" products with very little innovative content but a very high incidence.

"Line extensions," typically the introduction of a new flavor or a new size of a successful product, with limited innovative content.

True innovations that create new categories by satisfying new consumer needs, e.g., Activia, Actimel, Danacol and Essensis (a yogurt with a skincare benefit), which Danone regards as strong contributors to the $10 \%$ growth rate averaged by the Spanish dairy market over the last 25 years. 
According to Boesch, Danone España launches an average of 30 new products each year and discontinues an equivalent number. The big prize is at least one launch every two years that turns out to be a true innovation - and covers the costs of all the failures.

Some of the most successful examples of true innovation at Danone, especially in dairy products, do have the flavor of big science. Thus, over the last 90 years, Danone has built up a bacterial bank of approximately 3500 different strains of lactic bacteria. In addition to giving taste and texture, some ferments have probiotic health properties, e.g., the Bifidus DN 173010 strain that is used to produce Activia. Research on this resource continues, using state-of-the-art technologies such as genomics and robotics: only 100 of the strains have been studied systematically and only 50 are currently being used in products.

Looking forward, the food and beverages sector does seem to afford some significant opportunities for technology-based innovation: around health benefits (Danone's focus), convenience, and safety and environmental issues. But it is not clear whether increased emphasis on such attributes will relax what many observers cite as the key reason for currently low innovation rates in food and beverages: the rapid erosion of profit margins on innovations by the quick introduction of "me too" products and white labels in the event of success. And it seems unlikely that food and beverages is going to shift, after a long history of being a marketing-driven, advertising-intensive sector, into a technology-driven, R\&D-intensive one.

\section{Other Forms of Innovation}

If R\&D-based innovation seems an unlikely explanation for much of the rapid increase in labor productivity in food and beverages, what are the alternatives? One obvious possibility is to open up how one thinks about innovation as a way of picking up on a broader set of productivity enhancement mechanisms. The utility of doing so in the present context is highlighted by a study of Catalan firms that concludes that many of the food and beverages firms that are innovative do not have formal R\&D activities

A famous example of a product innovation that had limited science-based technological content but transformational impact based on its marketing power is provided by Freixenet's introduction in 1974 of its "Cordón Negro" cava in a specially ground black bottle; by volume, it is now the world's leading imported sparkling wine. So there are a range of possible functional bases/drivers of innovation, not just R\&D. ${ }^{4}$

Such broadening is clearly helpful - think, for example, of its implications for the usual attempts to grow productivity that focus most of their attention on the science $\rightarrow$ R\&D $\rightarrow$ innovation sequence - but it does not change the diagnosis of low innovation-intensity in food and beverages relative to other sectors. Thus, in Cassiman and Golovko's sample, only 13\% of the Catalan firms in food and beverages report themselves to be product innovators over 2000-2006 and 19\% process innovators, versus averages of 31\% and 36\% respectively for Catalan firms across all sectors. Despite the limited sample size, it is worth adding that these percentages have actually decreased slightly since the 1990s.

\footnotetext{
${ }^{4}$ Avermaete et al. (2004).
} 
Of course, the definition of innovation could be broadened further, beyond product and process innovations. There have clearly been significant services or business methods innovations, with logistics and distributions supplying a number of examples whose importance is amplified by the increasing concentration of food retailing in a few large chains of stores. On the other hand, since business method patents are not recognized in Spain (or most countries other than the United States), the appropriability regime looks even more daunting from the perspective of a potential innovator than is generally the case for more traditional innovations, especially on the product side. And one suspects that the implied scope for productivity growth resides to an even greater extent in imitation or replication instead of innovation, as discussed in a bit more detail in the next subsection.

Finally, one must also consider innovations that are so far-reaching in their implications as to warrant the appellation of business model or strategic innovations (with many variants). As Michael Porter recently put it,

"Strategy is all about innovation - innovation not necessarily in technology but in the way a company competes... My work stresses that there are many different ways to compete, many different ways to deliver value to customers, and many different customer needs."

Ricart and Casadesus-Masanell discuss such innovations, involving entirely new ways of competing, with a particular focus on looking for strategies that involve virtuous cycles or what they call "value loops". Other heuristics to help develop such strategies include understanding a company's strengths and weaknesses, considering a broad array of competitive variables (particularly the ones subject to significant irreversibility), exploring "hard" vs "soft" postures, thinking through changes in scope, geographic, vertical or horizontal, and shifting perspectives in a variety of ways: putting oneself in other players' shoes, identifying the unwritten rules that drive industry behavior and trying to break them, emphasizing threats (e.g., via devil's advocates or worst-case scenarios) as well as opportunities to increase receptivity to change, and thinking about how one might solve a particular problem if starting afresh or if money were no object, and so on. For additional discussion, see Cassiman and Ghemawat (2009).

One can certainly think of examples of strategic innovation within Catalan food and beverages or at least of innovation so broad that it cannot usefully be reduced to the categories previously considered. For example, about ten years ago Casa Tarradellas, a financially-stricken Catalan meat processing player, decided to reinvent itself by entering the convenience food segment and launching the first ready-to-cook fresh pizzas - with great success. Today the pizza product line and other chilled/ready-to-cook food contribute to more than half of the company sales $(€ 510$ million in 2007) and the company is building a new plant dedicated exclusively to ready-to-cook products. Note the successful addition of a whole new line of business!

The other aspect of the Casa Tarradellas example that is suggestive is that the company is often described as mid-sized rather than large - even though it ranks well within the top 1\% of Catalan food and beverage producers by size. While a focus on the largest firms as the basis for drawing up sector-wide recommendations is always problematic, it is especially so in food and beverages because the sector is very fragmented - not only in Catalonia or Spain but across Europe. In 2006, there were 2,876 Catalan food and beverage firms, of which only a quarter had more than 20 employees and only 3\% had more than 100 employees. And while there has been some increase in concentration, the share of output accounted for the five largest firms is only 12\%, up from 11\% in 1993 and still substantially lower than the average of 15\% across Catalan sectors. 
The fact that the typical food and beverage firm has less than 20 employees would seem to affect the general usefulness of injunctions to innovate and, in particular, to engage in strategic innovation given that that typically requires slack resources and is subject to increasing returns to scale. Put differently, it is useful to distinguish between class and mass: innovation and pushing the envelope make (comparatively) more sense for large, world-class firms, but it is also important to consider the large mass of other firms because, otherwise, one would focus just on the tip of the iceberg. The next subsection focuses on such firms in describing some mechanisms for productivity growth that are not based on innovation - although the mechanisms should also interest larger firms.

\section{Alternative Mechanisms}

Distinguishing between small and large firms helps explain part of the reason why productivity growth in the Catalan food and beverages sector, unlike a number of others, has been relatively rapid. Thus, in the Cassiman and Golovko sample of food and beverage firms described above, small firms (less than 200 employees) grew their productivity as fast as large firms (by nearly 40\% between 1990-1999 and 2000-2006).

But that distinction, applied to levels rather than changes, also suggests significant additional productivity improvement potential. The same sample indicates that firms with 50-100 employees have labor productivity more than twice as high as firms with less than 50 employees, and firms with more than 200 employees post levels that are two-and-a-half times as high. While some of the variation is accounted for by the non-homotheticity of production functions - the shift towards higher capital-to-labor ratios at greater scales of operation - this does not seem to be the entire explanation or even a large part of it.

\section{Figure 4}

Value Added per employee (thousand Euros)

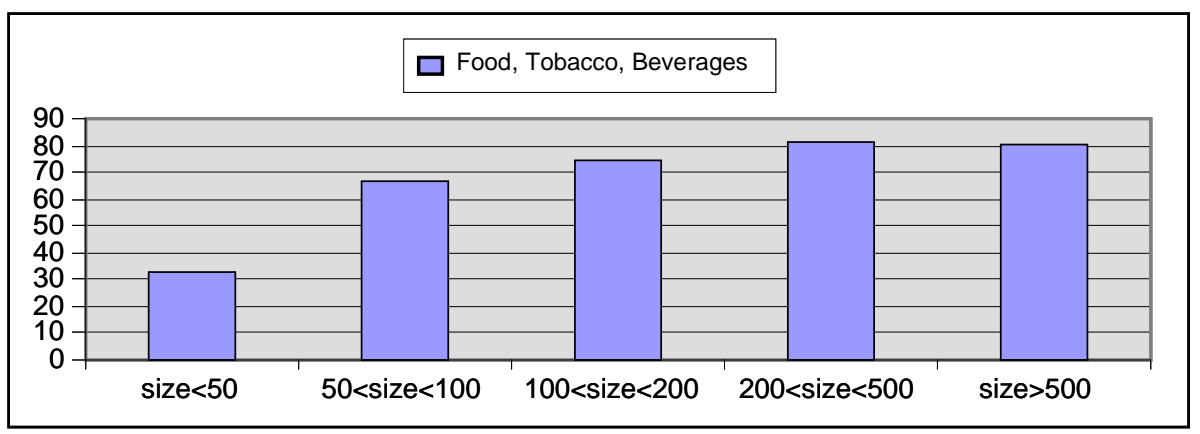

Instead, one is left with the impression of tremendous inefficiency, particularly at very small scales of operation. Cassiman and Golovko calculate that raising the mean labor productivity of the food and beverage sample to the mean for the food and beverage firms whose value added is more than the median value (i.e., bringing the mean labor productivity of the bottom half of firms up to the mean for the top half) would translate into a average productivity gain of 65\%!

Of course, the possibility of tapping even a fraction of this notional potential depends on why firms are operating inefficiently in the first place. One obvious possibility, especially given how small the small food and beverage firms are, is related to a failure to tap economies of scale leading to operations that are technically inefficient. While this may strike (some) economists as inconsistent with long-run equilibrium, it is worth recalling that the cross-country indicates 
that self-employment levels (an inverse measure of firm size) decrease at least up to the income levels achieved by Spain about two decades ago and that there are comparably long lags in adjustment to the levels predicted by the cross-country regression (Caves and Uekusa, 1976). A drawn-out consolidation process in the wake of rapid growth is, of course, consonant with the operation of a collectively substantial fringe at suboptimal scales for a long time. And rescaling to more appropriate sizes offers commensurately large improvement potential.

So scale, or lack of it, is one plausible explanation of why small firms are systematically less productive than large ones. But microeconometric studies as well as the managerial case study literature suggest the typical existence of other shortfalls that could be rectified without any innovation or vicarious learning of the sort necessary for imitation but aren't; i.e., offer lowhanging fruit for productivity enhancement initiatives. So rectification is potentially broader than just reaching efficient scale.

Rectification shades off naturally into the discussion of replication possibilities. In addition to making obvious fixes to their operations, productivity laggards can seek to improve by replicating or imitating productivity leaders - an activity that, by definition, does not have an innovative component. Interest in this mechanism in the food and beverage sector is increased by the low appropriability regime discussed above. But since appropriability does not seem to be the binding constraint, that shifts the spotlight to the absorptive capacity of smaller firms, and ways of improving it. It must be added that the interest in replication or imitation is far from confined to such firms: in an environment in which there is increased stress even within large companies on open innovation, perceptions of the best balance between innovation and imitation, in the sense of absorption from the outside, have shifted in favor of the latter.

Yet another distinct mechanism for productivity enhancement is provided by replacement or churn. While rectification and replication assumed that productivity laggards can be brought at least partially up to speed, replacement focuses on birth-and-death processes: on productivity growth among smaller firms/establishments, in particular through relatively efficient entrants pushing out some relatively inefficient incumbents. The importance of this mechanism is underlined by the conclusion that, in the United States, it accounts for more of the observed productivity growth than upgrading by establishments that continue in operation. In the specific context of Catalan food and beverages, Cassiman and Golovko's inspection of their sample suggests a significant incidence of drop-outs that probably partly reflects replacement processes, although further study is clearly needed. Corroboration is supplied by data suggesting that continuing plants in the Catalan food and beverages sector exhibit the second highest gross job creation and job destruction/replacement rates among 14 industrial sectors or combining them, the highest job reallocation rate overall. ${ }^{5}$ In other words, the (impressive) productivity growth of Catalan food and beverage firms seems to reflect not just existing firms upgrading but also displacement by other incumbents - the focus of the job data - and replacement by entrants.

Finally, even though the food and beverage sector appears, overall, in relatively good health, there are product lines - distinct industries within it, actually - that have experienced recurrent profitability problems in recent years. Such laggards point to the possibility that (improved) redeployment of productive resources can be another way of improving productivity without necessarily changing existing firms' behavior. The difference that redeployment (in)efficiency

\footnotetext{
${ }^{5}$ Camacho-Cabiscol, Alemany-Leira and Baró-Llinàs (2000).
} 
can make will be highlighted in the context of autos, where it looms larger because of Catalonia's rockier overall prospects in the long term.

To summarize this section, discussion grounded in the Catalan food and beverage sector and its relatively rapid rate of productivity growth has helped suggest a number of productivity enhancement mechanisms that are quite distinct from innovation: rescaling, rectification, replication, replacement and redeployment. And it would seem that their collective importance in the food and beverage sector at least is greater than that of innovation.

\section{The Automotive Sector}

Autos is a much more modern sector than food and beverages, and much less traditional to Catalonia. Worldwide, it dates back a bit more than 100 years, and a bit more than 50 in Catalonia, to the start-up of SEAT as a joint venture with Fiat. The sector's technology intensity is classified as medium-high by the OECD. Through the 1990s and the early 2000s, Catalonia (and Spain) generally ran international trade surpluses in the sector and, despite recent stagnation and even shrinkage, its weight in Catalan industrial production is still very substantial. For all these reasons, autos has generally been accorded more emphasis in discussions of Catalonia's long-term industrial base than, say, food and beverages. In particular, this presumption is what seems to underlie the Generalitat's regular willingness to offer (additional) aid to keep vehicle assembly capacity - owned by Volkswagen/SEAT and Nissan in Catalonia. But, as in the case of food and beverages but for diametrically opposite reasons (Catalan un-productivity versus productivity), this seems to be the wrong conclusion.

The regular aid requirements should be a basis for questioning the presumption that all the existing parts of the auto sector can and should be kept in Catalonia. They are indicative of a significant competitiveness issues. One indication is provided by recent changes in Catalonia's external trade balance: its international trade surplus in autos peaked in 2000 and then declined, to levels that turned negative starting in 2004. And its interregional trade surplus turned (slightly) negative in 2006, for the first time in the sector's modern history. To provide additional background, interregional trade has run at about one-half the level of international trade in recent years - the exact opposite of the pattern for food and beverages, and reflective of the greater international border effects in food and beverages than in autos. But international trade in autos is, like that in food and beverages, highly regionalized (in the sense of international rather than intranational regions), with about two-thirds focused on the EU.

This deteriorating external performance is exactly what one would expect given the underlying productivity levels and growth. Thus, Jaumandreu's data indicate slower labor productivity growth in this sector over 1995-2003 - at an annual rate of 0.5\% - than any of the other twodigit Catalan sectors studied, as well as productivity levels inferior to the EU-25 averages. To triangulate, in Cassiman and Golovko's sample, average labor productivity in autos increased by 19\% in real terms between 1990-1999 and 2000-2006, about one-half as much as in food and beverages. Clearly, greater technological intensity does not always imply faster productivity growth.

The labor productivity growth rate estimated for autos in Catalonia is worth juxtaposing against McKinsey's estimates of a 4.5\% growth rate in the United States and 2.2\% in the EU-15 over 1995-2002. The differential with the EU-15 swells over seven years into a 13\% productivity gap, and that with the United States into a 32\% gap. Note that such gaps should be 
expected, especially in a sector where border effects are relatively small, to put pressure on employment (which has declined by more than 10\% since 2000) or compensation (which has increased at a faster clip) as well as on returns to capital since labor's share of national income typically exceeds capital's - and since profitability in autos is already low. Operating profit margins have declined more or less continuously from about 10\% of sales in the mid-1990s to about 5\% by the mid-2000s - even before the current economic downturn, which by fall 2008 had reduced Spanish vehicle sales by an estimated 25\% relative to the previous year. The difficulties in Catalonia in this regard mirror some of the profitability pressures in a broader global context driven by entry and significant excess capacity, which have already bankrupted a large number of Tier I auto parts suppliers in the West and are now threatening some of the OEMs, particularly US-headquartered ones.

Given this productivity and profitability squeeze, the reasons for low productivity growth and possible responses are worth understanding in more detail.

\section{Productivity Growth Mechanisms}

To begin to understand what has been going on in the sector, it is useful, once again, to consider the size distribution of players within it. Autos is a bit less fragmented than food and beverages but there is still a long tail of very small firms: two-thirds of auto establishments have fewer than 20 employees, compared to three-quarters in food and beverages. Cassiman and Golovko's sample suggests a number of problems with the left tail of the size distribution in auto, starting with the following disaggregation of labor productivity:

\section{Figure 5}

Value Added per employee (thousand Euros)

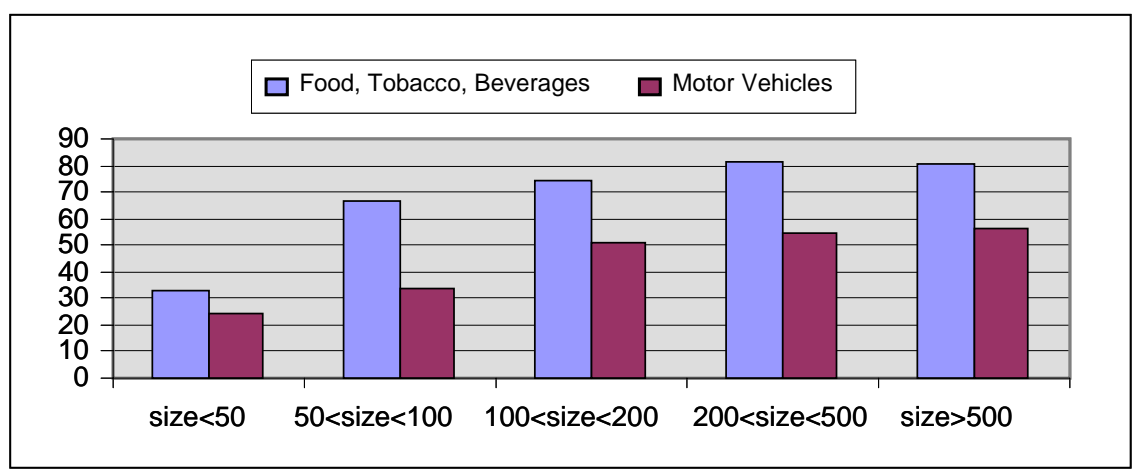

Note that labor productivity in each size class is lower than in food and beverages. The very low value added per employee in the smallest size group is a matter of particular concern since jobs that add this little value are unlikely to support acceptable standards of living. And the alarm around these low productivity levels is amplified by patterns of change. According to Cassiman and Golovko, average labor productivity for the small automotive firms in their sample actually decreased by 8\% in real terms between 1990-1999 and 2000-2006, pulling down the sector-wide average to $19 \%$.

What are the implications of this set of facts for the productivity enhancement mechanisms identified in the previous section? Especially given its technology-intensity, the auto sector clearly affords significant room for innovation. Examples include the location of design and testing activities by auto OEMs in the area and the innovations developed, in particular, by the four large 
Tier I suppliers that are locally headquartered (see Box B for an example). But again, innovation of whatever kind is unlikely to be the solution for firms with fewer than, say, 20 employees - two thirds of the population. In line with that reality, auto firms describe themselves, in Cassiman and Golovko's sample, as product innovators (17\%) and process innovators (28\%) at rates only slightly greater than their counterparts in the food and beverage sector.

In terms of other mechanisms for productivity growth, the very poor performance of the smallest firms draws attention to scale, in particular, as a potential rectification mechanism. The scope for rectification plus replication, or what one might call remediation, is illustrated by Cassiman and Golovko's calculation that raising the mean labor productivity of the auto sample to the mean for the firms whose value added is more than the median value (i.e., bringing the mean labor productivity of the bottom half of firms up to the mean value for the top half) would translate into a average productivity gain of $38 \%$. This is less potential for remediation than in food and beverages, but twice the actual gains in autos between 1990-1999 and 2000-2006.

Reaching beyond remediation also seems important, however, because based on their recent records, it is not clear how capable some of the laggards actually are of improving their performance. Replacement of inefficient incumbents by more efficient entrants is an obvious alternative that appears not to have worked well in autos: exit rates in the Cassiman and Golovko sample do not appear to have been high despite the parlous performance of the laggards. Corroboration is supplied by data suggesting that continuing plants in the Catalan auto sector ranked below those in food and beverages both in terms of annual (gross) job creation (6\% versus 7.8\%) and job destruction or replacement (3.1\% versus $4.4 \%$ ); also implying a lower ratio for autos of jobs replaced to net jobs created. ${ }^{6}$

Of course, part of the problem underlying weak replacement effects in autos may be that the entry that is supposed to spur exit may itself have been curtailed by the reduced incentive to invest in a sector with low and declining average profitability. A decade-plus of declining profitability isn't just a sequence of unfortunate events: it reflects the structural pressure experienced by Catalonia and, more broadly, Spain, as a base for auto parts and assembly. When significant auto OEM investment was attracted to Catalonia/Spain through the early 1990s as an export base (a requirement, early on) as well as to serve the domestic market, cheaper labor than elsewhere in Western Europe and cheap capital through subsidies of various sorts were major motivations. It is intriguing to speculate - in this sector and in a more general Catalan or even Spanish context - whether this "cheap resource" mentality has anything to do with the low rate of productivity growth in recent years - a linkage also cited by Ricart and Casadesus-Masanell later on in this volume.

Whatever the reasons, it is clear that the current situation is a crisis not just because of the shock to demand in Europe and, particularly, Spain but also because of longer-term challenges to Catalonia from low-cost Eastern European and other countries in an industry with increasing cross-border labor arbitrage. These challenges are discussed in the next subsection. What is to be noted here is that if significant slimming is indicated for the Catalan automotive sector, as seems to be the case, that makes redeployment of labor, capital, etc., a mechanism with major impact on economic value created or destroyed. In such a context, to offer subsidies to protect auto sector jobs is to spend money to retard the (overdue) redeployment of labor and, furthermore, to weaken efficiency incentives for labor and management. Protectionism of the sort recently mooted is

\footnotetext{
${ }^{6}$ Camacho-Cabiscol, Alemany-Leira and Baró-Llinàs (2000).
} 
similarly bad, although it makes local auto buyers pay more to preserve autoworkers' jobs, instead of the general taxpaying public. These points will be revisited in the next section, after we take an international perspective on Catalonia's position and prospects in autos.

\section{International Competition}

The temptation to leap from the preceding characterization to the proposal of productivityimprovement initiatives and other policy implications is strong but will be resisted. Such a leap would short-circuit more basic consideration of the long-term viability of the auto sector and, in particular, final assembly in Catalonia - relevant, among other things, to decisions about how much attention to devote to specific initiatives. Modern strategic analysis stresses that such viability must be assessed relative to competitors, rather than simply assumed or worked towards - and that competitive advantage is especially important when average industry profitability is too low for financial viability, as appears to be the case for autos. And comparisons with international competitors are indicated by the low international-to-interregional border effect estimated for this sector - and by the specific pressures being experienced by auto competitors in Catalonia, and in Western Europe in general.

Overall patterns of international trade and investment in autos are highly regionalized: more than $80 \%$ of Catalonia's international exports and more than $70 \%$ of its imports involve other EU members. And even firms that have broad global presence (e.g., Toyota and Volkswagen) tend to compete on a region-by-region basis. Within the European region, the biggest single shift has been the migration of competitive advantage to the post-socialist East European countries, particularly the ones in the "near east" that have become members of the EU. Since the early 1990s, new assembly capacity has all been located in East Europe: Volkswagen's investment at Martorell 15 years ago was the last such major investment by a Western auto manufacturer in all of Western Europe! Given conditions in Catalonia, not only is assembly capacity unlikely to be added but even existing capacity may migrate - to Eastern Europe or to other low-cost locations.

Start by looking at within-factory costs. Labor costs represent the obvious big difference here, but one that still needs to be emphasized because of labor costs in Eastern Europe that are still a fraction - in some cases, still much less than one-fifth - of Catalan levels, the high total labor content of the final product, and a number of misconceptions about labor costs that tend to diminish their true importance: see Box B.

\section{Box B}

\section{Myths and Realities of Labor Arbitrage by Eastern European Auto Manufacturers}

Myth 1 . Direct labor accounts for only $20 \%$ or so of the value of an assembled vehicle.

Reality 1 . Such statements focus on labor costs at just the final assembly stage, although labor costs actually add up along the value chain: purchased parts, material costs and services each have significant labor content. It is estimated that labor costs account for at least $65 \%$ of total manufactured cost of the final product.

Myth 2. Eastern European labor costs are rising faster while labor productivity there is lower. 
Reality 2. This is misleading both because labor productivity is already high in some East European countries - Volkswagen, for instance, transferred state of the art technology to Skoda - and because, where it isn't, it is improving rapidly. In addition, even if one ignores these productivity-related points, labor cost convergence is a distant prospect: with an initial cost ratio of 1:4, say, 10\% higher labor cost inflation in Eastern Europe would have to persist for 15 years to push up costs to Western European levels.

Myth 3. Eastern European labor is less skilled than Catalan labor.

Reality 3. The new EU members in the east not only have higher general educational levels than their eastern neighbors but also surpass Western Europe. Thus, the proportion of workingage (25-64 years) people who have finished schooling successfully at least to a secondary (II) level averaged 78\% in 2004 in the new EU members, versus 64\% in the EU-15. And in terms of higher education and training, the Czech Republic and Slovenia, for instance, are ranked ahead of Spain.

Sources: Myth/reality 1 based on estimates summarized in Helmut Becker (2006). Myth/reality 2 draws its broad outlines from looking across several international comparisons of costs and productivity. Myth/reality 3 draws on data from Eurostat and from the World Competitiveness Report for 2008-2009 from the World Economic Forum.

Capital costs also tend to be lower in Eastern Europe: construction costs are 15-30\% cheaper there than in Spain, according to a Gardiner \& Theobald survey (International construction cost survey December 2003). Additional capital economies can be achieved by sourcing equipment locally, using fewer and smaller assets, increasing hours of operation towards 24/7 and replacing capital with labor. A dramatic example of capital-labor substitution is provided by Renault's plant in Pitesi, Romania, to make the Logan, the $€ 5,000$ global car for lower-income markets. Instead of 1,000 robots, 2,000 workers were employed for manual assembly at a full cost of less than $€ 300 /$ month. This helped bring the total investment down to about $€ 500$ million, from $€ 700-800$ million for a traditional plant.

Looking beyond the factory walls, there are logistics costs. According to local industry (which wants government to do something about this), these can add up to 25\% of autos assembled in Catalonia. There are almost certainly important infrastructural problems that Catalan policymakers can and should address. But it is also worth emphasizing that, from a geographic perspective, Catalonia faces structural disadvantages vis-à-vis East Europe as a base for serving markets in Northern/Central Europe because of the distance implied by its southwestern location, aggravated by the incompatibility of Spanish and French train gauges. A range of studies suggests that, overall, a 1 percent increase in the distance between two countries or regions tends to decrease trade between them by about 1 percent. By this metric, because Barcelona is more than five times as far, as the crow flies, from Berlin as Berlin is from Prague, Czech-German trade should be five times as intense as Catalan-German trade for this reason alone. ${ }^{7}$

The bases of Eastern European external competitiveness in this sector extend beyond economic advantages and geographic proximity to Western Europe (including, in the Polish and Czech cases, a land border with Germany) to include more subtle administrative and cultural similarities that also facilitate cross-border exchange. Most obviously, membership in the EU implies extensive efforts at administrative harmonization that should ease such interactions. In addition, a number of countries within Central/Northern Europe have colonial ties (e.g., through

\footnotetext{
${ }^{7}$ Note that the median distance across all possible country-pairs falls in between these two distances.
} 
the Austro-Hungarian empire), to similar effect. And then there are cultural links through languages and the diaspora between Germany/Austria in particular and the new EU members.

To summarize, the new Eastern European members of the EU exhibit cultural, administrative and geographic similarities to the EU-15 as well as economic differences that lower their costs. The notion that such similarities can ease cross-border interactions may not be startling, but estimates of the sizes of their effects have that character. Figure 6 summarizes the results of some statistical analysis of bilateral trade flows between every possible country-pair in the world. ${ }^{8}$ It implies that two countries characterized by all five of the commonalities listed in the figure should be expected to trade 29 times as much with each other $(1.42 \times 1.47 \times 2.88 \times 2.14$ $x$ 2.25) as an otherwise similar country-pair without any of these commonalities. ${ }^{9}$ It is worth adding that these estimates are generally lower than those in other widely-cited studies.

\section{Figure 6}

Effects of Similarities versus Differences on Bilateral Trade

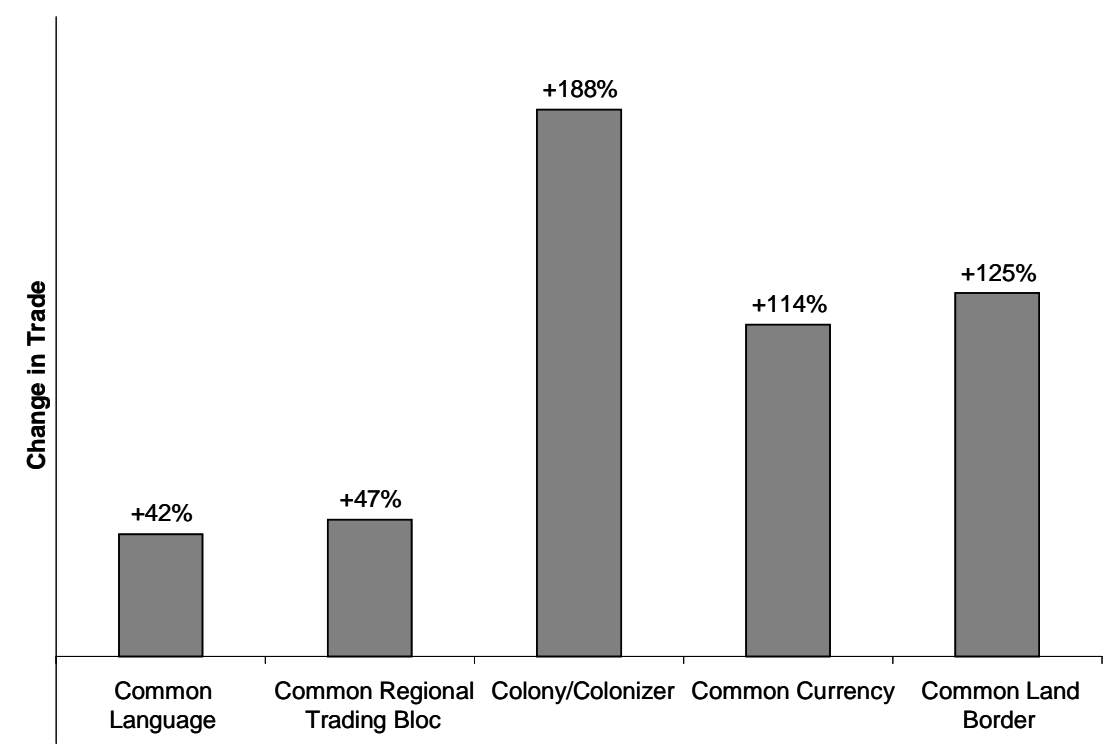

The same types of linkages - cultural, administrative and geographic - can be used to identify other low cost competitive threats to Spanish/Western European capacity. Morocco is not an EU member but is close to it along several dimensions, possessing cultural and administrative affinities with France in particular as well as geographic proximity to Spain, along with a large pool of low-cost labor. Labor costs are even lower in Asia of course, but China and India aren't as proximate culturally, administratively or geographically. They therefore seem to be worth thinking about as very large, rapidly growing pools of demand at very low price points as much as platforms for labor arbitrage - although the latter is certainly starting to happen as well, especially in auto parts (see Box C for an example).

\footnotetext{
${ }^{8}$ The estimates reported here are based on my own work with Rajiv Mallick and, although still very large in absolute terms, are significantly lower than the ones reported in my 2001 HBR article, which were based on early work by Frankel and Rose (2000). Our lower estimates mostly reflect our greater care in dealing with numerous observations coded as 0 and our stricter focus on separate countries as opposed to politically distinct entities.

${ }^{9}$ Ghemawat and Malik (2003).
} 


\section{Box C}

\section{East of Eastern Europe}

It isn't simply the world's fastest growing OEMs that are located in Asia but also some of the fastest growing auto parts units. An example is provided by Mahindra Systech, one of India's top 5 auto parts companies and already one of the world's five largest forging companies, thanks to international acquisitions and joint ventures, which has multiplied in size by several times over the last five years, to approximately $\$ 1$ billion in revenues. Systech has aggressive growth aspirations and focuses on parts that are not too bulky, don't involve plastic, and have relatively high engineered content relative to run length (it considers the Chinese more competitive on very high volume parts). In addition - and this represents an outsourcing opportunity as well as a threat of displacement for Catalan parts suppliers Systech is also the umbrella for the Mahindra Group's attempt to sell engineering services, another major focus for Indian competitors. Benchmarking against such players as well as players based in Eastern Europe is essential for informed parts portfolio selection - instead of simple nostra such as "Target more highly engineered parts." Engineers tend to be cheaper in low cost countries as well.

Perhaps the most reliable insights into how auto OEMs with Western European manufacturing capacity will respond are obtained by adopting their perspectives. Look at the world from the perspective of Volkswagen's top management. Of the seven businesses for which Volkswagen disaggregates operating income, SEAT was the clear underperformer in 2007 (see Figure 7). Furthermore, 2007 was actually a better year for SEAT than the immediately prior ones - and 2008 will be much worse. In addition, one must consider some of the constraints of the Martorell plant (basically, it was oversized and overly expensive per unit of capacity), the lack of a clear positioning for SEAT within Volkswagen's portfolio now that Skoda has become the "economy" offering, and the move to make some SEATs in Latin America. Given all this, SEAT's Catalan assembly capacity would seem a leading candidate for closure, especially as Volkswagen's new owner, Porsche, takes charge. And more briefly, the local assembly capacity of the other OEM, Nissan, which has already announced a plan to cut back its Catalan operations significantly, is threatened on a longer-term basis by its investment in a large new plant in Morocco. With much lower-cost capacity there, Nissan will require regular sweeteners - or strong persuasion of some other stripe - to keep higher-cost capacity running in Catalonia.

From a sectoral perspective, this means that the Tier 1 suppliers and their ability to sell to OEM operations outside Catalonia is one of the critical determinants of the long-term retention of auto parts capacity in Catalonia, even if all the assembly capacity gets unwound. To some extent, locally-headquartered Tier I suppliers are already playing this game: while Volkswagen continues to operate assembly capacity in Catalonia, procurement decisions for SEAT reportedly migrated years ago to Wolfsburg. The challenge, of course, will be to get better at this, and to try to penetrate OEMs that don't have Catalan/Spanish linkages, including some of those headquartered in Asia and growing at above-average rates. And of course, Box B suggests that Catalan manufacturers will need to be selective even in auto parts. 


\section{Figure 7}

Volkswagen's Product Portfolio, 2007

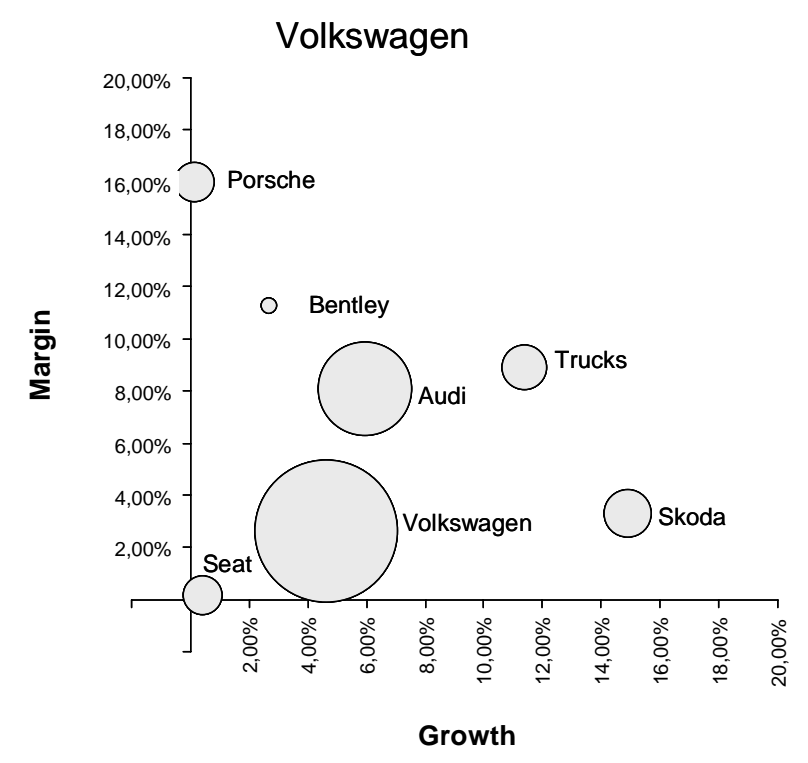

It would be useful to backstop these conclusions with more detailed comparisons of the end-toend economics of the auto value chain in different locations, that ideally look at total factor productivity instead of just labor productivity and take a dynamic perspective - one that recognizes above-average rates of inflation in Spain relative to the rest of the Eurozone, faster productivity growth in East Europe, etc. But pending such further study, the comparisons developed in this section do suggest that the Catalan automotive industry will need to slim down substantially to be internationally competitive. Efficient redeployment of labor and capital away from autos, rather than just more efficient employment of those resources within the sector, therefore looms large, especially given recent policy announcements, as discussed in the next section.

\section{Productivity-Related Implications}

The sectoral studies were painted with a very broad brush across very diverse sectors. Partly for that reason, this section will focus more on elucidating the broad conceptual and policy implications of the sectoral studies than on providing a swarm of policy recommendations: the latter often have to be tuned to the industry rather than the sectoral level and, in any case, are available from a variety of sources.

\section{Productivity Growth Mechanisms: Renovation as Well as Innovation}

Much of this chapter has been aimed at broadening the discussion of productivity growth beyond the narrow techno-fetishism of science-based innovation and the inferred optimality of R\&D subsidies of various types. While various approaches to broadening have already been mentioned in the context of the two sectoral studies, they are worth discussing somewhat more systematically and generally. Consider, first, the varieties of innovation: 
- Many innovations, even at the level of specific products, have very little S\&T content. This is obviously true of many incremental product innovations. A transformative example of this sort is supplied by Freixenet's famous black bottle and labeling for its cava.

- Process innovations tend to involve comparatively more development and comparatively less research than product innovations - and generally seem to be subject to less appropriability by innovators.

- Then there are service innovations, which often rely heavily on information technology. Thus, innovation in autos is not confined to better (or cheaper) cars: onboard GPS has sparked a surge of service applications ranging from traffic management - of interest to highway operator Abertis as well as automakers - to customized pricing of insurance by route and time.

- It is possible to envision an even broader class of innovations than the provision of a better product or service. Mango, for instance, has prospered in clothing by developing an information and logistics system that might be classified as a service innovation but that seems so far-reaching in its implications as to warrant separate categorization, as a business model or strategic innovation.

Even more than these innovation categories, however, the two sectoral studies, and particularly the one on the low-R\&D food and beverage sector, focused our attention on renovation-based mechanisms for productivity growth: mechanisms that do not (need to) involve innovation in the sense of anything new to the world.

- Reaching efficient scale, eliminating bottlenecks and effecting other rectifications often afford opportunities that are so obvious that no new information is required to spot them; rather, what is required is managerial action. The long tail of small firms with low productivity levels in Catalonia supplies an obvious example.

- Replication does involve looking outside the firm but, like the other efforts at remediation already listed, it focuses on moving firms that operate within the production possibility frontier closer to that frontier. Its importance is flagged by findings ranging from imitation being cheaper and quicker than innovation to the observed dominance of the gains from major innovation by their diffusion.

- Replacement of the less efficient by the more efficient is highlighted by studies of plantlevel entry and exit which suggest that, especially in the United States, this mechanism accounts for more productivity gains than upgrading by existing establishments. The importance of replacement seems lower in Europe, but many authors argue that that is a large part of the problem - and that policies that ease entry and exit are sorely needed (e.g., Aghion).

- Redeployment of factor inputs from one sector to another focuses attention on allocative efficiency across sectors rather than technical efficiency within them. Polities are not all equally effective at resource redeployments, which can therefore make a significant difference. For example, given the size of the Catalan auto sector, whether the government obstructs or eases its restructuring is likely to have a discernible impact on overall economic performance.

In other words, if one starts with the basic accounting identity linking output to productivity, Total Output = Factor Inputs ${ }^{*}$ Total Factor Productivity,

all of the points bulleted above should be thought of as mechanisms for raising total factor productivity. 
The other term included on the right-hand side of the equation reminds us that output growth reflects factor accumulation as well as productivity growth. Factor accumulation is, within economics, an old story: the modern productivity literature can be read as aiming to demonstrate that factor accumulation is less important - and productivity growth more important - in explaining output growth than people used to think. It also has a well-established place in Catalan/Spanish policy debates: the key long-term concern is that pre-crisis growth may have been driven more by factor accumulation (particularly the import of cheap labor and capital) and less by productivity growth than other advanced economies, particularly the United States.

Finally, the discussion so far - of factor accumulation as well as various mechanisms for productivity growth - has focused on the supply side. But there is a long and distinguished body of evidence, on the important demand-side as well as supply-side influences on innovation, in particular. Griliches and Schmookler's classic works on the subject were published more than half-a-century ago. More recent contributions, to focus on a few just in management, include Eric von Hippel's work on lead-user innovation, C. K. Prahalad's insistence on the co-creation of value with customers, and Amar Bhide's research on venturesome consumption and in particular, iterated development with buyers by a sample of startups funded by venture capitalists. Recent microeconometric studies, pointing to the importance of idiosyncratic demand shocks in driving productivity growth point towards the demand side as well.

In the Catalan context, Cassiman's work on the problematic links between science and business and, with Golovko, on the importance of imports, also signal, albeit in different ways, the importance of the demand side or of consumption. Yet it remains invisible in many policy discussions of how to encourage productivity growth, for reasons that ranging from a failure of expenditure-based measures to pick-up on buyer surplus to a neomercantilist preference for production over consumption. These aren't good reasons, however, to ignore how demand interacts with factor stocks and institutional arrangements to influence innovation, imitation, replacement and redeployment.

These diverse mechanisms and influences can be assembled into a House of Growth, as in Figure 8. This depiction reminds us of the range of approaches to growing economic output - and puts specific policy levers into perspective, as will be discussed next.

\section{Figure 8}

The House of Growth

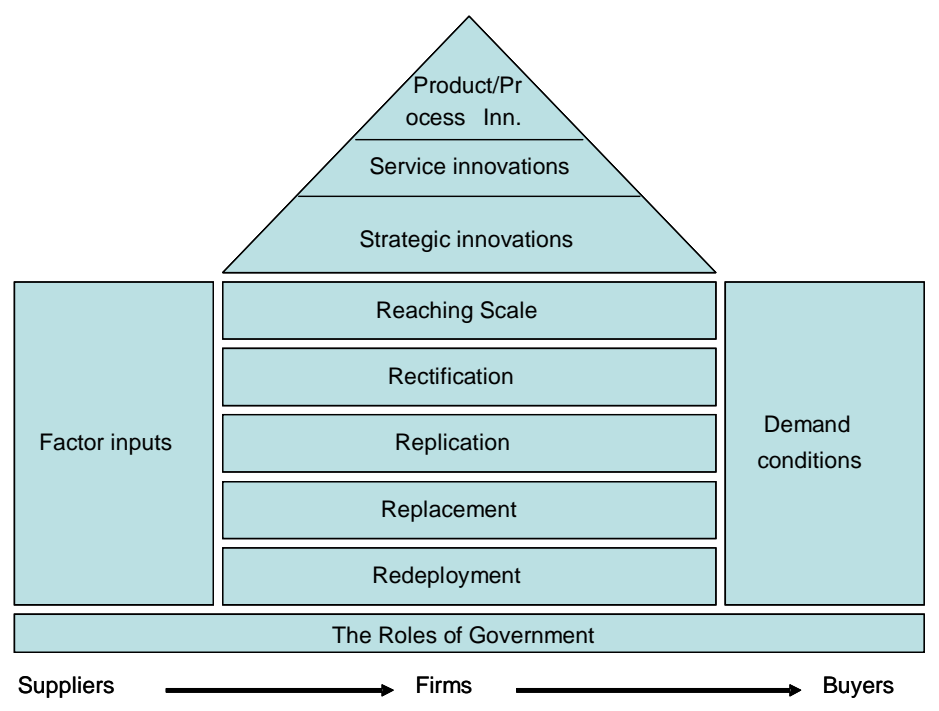




\section{Policy Levers}

In addition to calling attention to the broad array of conditions and mechanisms that determine productivity growth, the House of Growth helps structure a discussion of how governments can influence their operation - in terms of the relationships between the base of the house, involving the government, and its other parts.

It is useful to begin by distinguishing between two roles that governments can play in influencing outcomes: as players or transactors in the marketplace - as suppliers of inputs or other essential complements, as competitors (or joint venture partners) in offering products or services, or as buyers - and as rulemakers. As players, governments tend to have recourse to the same kinds of market instruments as private firms, but with differences in terms of scale (typically much larger if consolidated), incentives, power and, frankly, management depth. Rulemaking is a higher-level influence: governments determine the rules that govern the operations of markets, including those in which they are not present as transactors. Rules are myriad, and greatly expand and complicate the government's strategy space: they include taxes, subsidies, price/profit restrictions, disclosure requirements and other financial regulation, product/process regulation, local content requirements, trade/industrial policy, governmental ownership by statute, local ownership/ partnership requirements, competition policy, restrictions on entry/expansion, patent law, intellectual property right recognition and enforcement, technology transfer policies, and so on. And then there is the apparatus for adjudicating and enforcing them.

Discussing each of such a large number of categories is beyond the scope of this chapter. Rather, this subsection will focus on registering some productivity-related points about the appropriate scope and content of governmental policy that are organized in terms of the House of Growth.

In terms of ensuring a supply of factor inputs, governments bring a variety of influences to bear ranging from overall macroeconomic and financial management to earmarks for specific sectors or types of firms. The role of the government in actually being involved in the provision of inputs, especially specialized ones, as opposed to influencing their provision, is more controversial. It is certainly possible to think of cases where public involvement proved beneficial even in the context of great specialization, e.g., the auto testing facility at Manresa in Catalonia. On the other hand, simply to draw up a list of industry pleadings about inputs that the government might improve the quantity/quality of would be to risk succumbing to the simple logic that it is preferable to spend money out of public funds than one's own purse.

Since the public funds - and bandwidth - available for this purpose are limited, a sensible test of when to use them is the one provided by market failures: would private provision be subject to one of the standard categories of such failures associated with increasing returns to scale (e.g., infrastructure and information), public goods/non-excludability (e.g., healthcare and education), and uncertainty/missing markets (e.g., social safety nets)? And as public institutions aren't always better managed than private institutions, it is worth adding a second test: is public provision actually likely to lead to a better outcome than that provided by second-best (regulated) private provision? In other words, it is important to make sure that the proposed solution (public provision) isn't even worse than the problem (private provision that falls short of the first-best).

The demand side has attracted less attention in the framing of governmental policies than the supply side but, again, some focus areas can be identified. Macroeconomic management is important here as well, with countercyclical/stabilizing policies meriting special mention. The

IESE Business School-University of Navarra - 21 
stop-go character of many publicly financed initiatives is problematic in this regard and suggests another heuristic about when to start an initiative that requires ongoing commitment of resources: only when it can be sustained through cyclical downturns. Additionally, governments can influence the sophistication of demand, both as transactors (government accounts for 10-20\% of final consumption demand in most countries) and as rulemakers (through tax policies, standards, etc.). And they can even try to influence buyer adventurousness in both those roles. The point is that demand matters even if one takes an innovation-centric view of productivity growth potential.

The rest of the House of Growth, which plays out at the firm level and bridges between suppliers and buyers, involves innovation and renovation. Regarding the former, the key point is that the traditional science $\rightarrow$ research $\rightarrow$ innovation sequence touches only the product and process innovations at the tip of the House of Growth, and then only a subset of them. The other observation to be made about this category is that the results of basic investments in science are often not appropriable - such knowledge tends, among other things, to be relatively mobile geographically - so the case for taking advantage of knowledge developed elsewhere, and husbanding scarce resources for investment in other ways, has to be taken seriously. Turning to service innovations, these often have an information technology component and need their own kind of attention, given the EU's generally poorer track record in this respect than the United States. And strategic innovations really fall squarely into the firm domain: it is hard to see what government can provide in this regard beyond general encouragement. But of course, there is no way to avoid figuring out how specifically to exploit this or other productivity enhancement mechanisms - rather than just influencing their conditions of operation - if the government is a transactor as well as the rulemaker (e.g., education, healthcare).

The untapped potential for governmental rulemaking to improve productivity really seems to be concentrated under the heading of renovation. In particular, the existence of a long tail of small firms with very low productivity levels suggest that a major avenue for productivity growth and job creation is to figure out how to improve the productivity of very small firms with, say, fewer than 20 employees. (According to some early data, chosen for comparability with the table below, plants with fewer than 20 employees account for 38\% of employment and $52 \%$ of gross job creation in Catalan industry and firms with fewer than 50 employees for 55\% and $68 \%$ respectively.) This also tends to be the most dynamic size category in terms of job reallocation across continuing plants (see Table 1).

\section{Table 1}

Gross Job Flows by Plant Size (Annualized, as Fraction of Employment)

\begin{tabular}{lccc}
\hline Plan size & $\begin{array}{c}\text { Job } \\
\text { Creation }\end{array}$ & $\begin{array}{c}\text { Job } \\
\text { Destruction }\end{array}$ & $\begin{array}{c}\text { Job } \\
\text { Reallocation }\end{array}$ \\
\hline $1-10$ & 0.0975 & 0.0251 & 0.1227 \\
$11-19$ & 0.0647 & 0.0349 & 0.0997 \\
$20-49$ & 0.0539 & 0.0326 & 0.0865 \\
$50-99$ & 0.0446 & 0.0409 & 0.0855 \\
$100-249$ & 0.0500 & 0.0343 & 0.0843 \\
$250+$ & 0.0385 & 0.0394 & 0.0779 \\
Wt. Average & 0.061 & 0.034 & 0.095 \\
\hline
\end{tabular}

Source: Camacho-Cabiscol, Alemany-Leira and Baró-Llinàs (2000). 
The job reallocation rates in the last column in the table offer evidence of great heterogeneity in employment growth experiences across firms within very narrowly defined size classes, and hint at the potential for remediation. Note that the kind of remediation required to improve the productivity of firms with fewer than 20 employees is likely to depend less on innovation and more on rescaling, rectifying obvious deficiencies and replicating the better practices of betterperforming organizations. Making progress along these dimensions will require the identification and relaxation of key constraints, the sharing of best practices across firms and perhaps even the provision of basic extension/consulting services - ideally, given the number of firms involved, with a degree of scalability across firms. It is worth adding that since small firms are also probably the most vulnerable to the contraction in bank credit, many may need help to survive the crisis, but such help will represent an efficient deployment of resources (rather than a failure to redeploy) only if there is some way to turn small firms that have persistently destroyed economic value into enterprises that actually add to it.

While the job flow data above illustrate the extent of displacement of inefficient incumbents by more efficient ones, their replacement by more efficient entrants is generally thought to pack even more productivity enhancement potential in most contexts. Again, such birth-and-death processes tend to be concentrated among the smallest firms. Maximizing their potential requires governments to ease barriers to entry, expansion/contraction and exit, rather than to protect firms in a particular size class, whether the smallest or some other. Particularly deleterious in this regard are size class preferences that discourage growth from one size class to the next. Also note the implication that preferences allotted to incumbent firms in a particular sector should, in principle, be made available to entrants as well.

Finally, efficient redeployment requires recognition that not all jobs, not even in the most cherished sectors, can or should be protected. Consider the case of auto final assembly, in which international comparisons did not redound to Catalonia's advantage. If that is an accurate diagnosis, trapping resources within the sector is costly and wasteful. It probably also delays the development of alternate, more sensible plans for how to proceed. And since the attempt to protect all the jobs is unlikely to succeed, it also carries a cost in terms of governmental credibility. The clear policy implication for now is recognizing when resources need to be redeployed.

\section{Industry Portfolios}

The redeployment of resources, e.g., from sunset to sunrise sectors, is considered so important that some describe it as the key function of industrial policy. It is not within the scope of this chapter to specify the appropriate degree of governmental activism in re-optimizing industry portfolios. But one does not have to take a particular perspective on that issue to take an interest in developing a more systematic basis for thinking about the broad portfolio of industries, which is the focus of the treatment here.

Industry portfolio analysis for governments still often embodies the portfolio planning techniques consulting firms developed 40 years ago to help large corporations assess the relative potential of their businesses for investment. Broadly speaking, these techniques involve positioning of diverse businesses on a grid, with some proxy for competitive position on one dimension of the grid and some proxy for market potential on the other. The earliest example is provided by the Boston Consulting Group's share/growth matrix (see Figure 9). BCG focused on relative market share as its proxy for competitive position - in the belief that costs go down forever with scale/experience - and historic market growth as its proxy for market potential 
and investment-intensity. Its basic strategy recommendation was to maintain a balance between "cash cows" (that is, mature businesses) and "stars," while allocating some resources to fund "question marks" (that is, possible stars given the potential to increase share in highgrowth arenas) and selling off "dogs."

\section{Figure 9}

The BCG Matrix

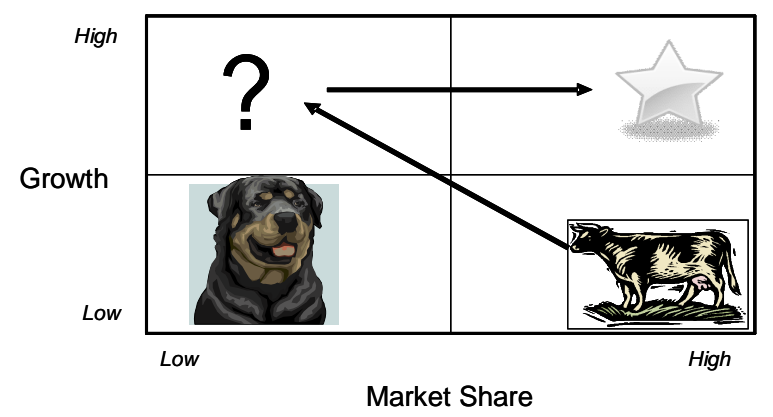

A recent application to Catalonia's industrial portfolio is provided by Torrens and Raluy (2008), who change the horizontal dimension of BCG's $2 \times 2$ matrix from relative market share to Catalan specialization levels, and come up with the classifications - and implied investment recommendations - in the figure. Note that the two sectors discussed in this chapter are classified in the same way in their matrix, as high-specialization, low-growth sectors that Catalonia should treat as cash cows and milk.

\section{Figure 10}

Catalan sectors in the BCG Matrix

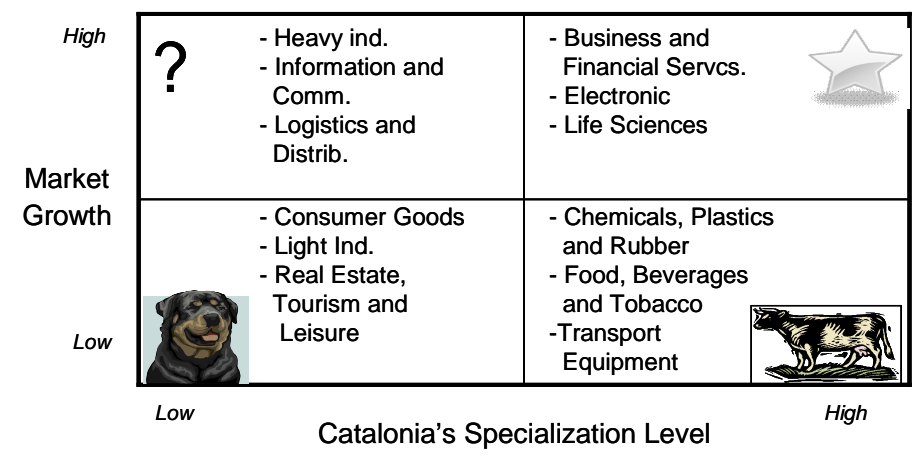

Source: Torrens and Raluy (2008).

This putative similarity in positions is hard to reconcile with the relatively optimistic prospects for Catalonia in food and beverages and pessimistic ones in autos. A re-conceptualization that refocuses the grid on productivity-related considerations fits better with the central thrust of this chapter as well as with the different diagnoses of the two sectors. An obvious productivitybased measure of relative position is provided by Catalonia's labor productivity relative to the EU and of potential by productivity growth rates (see Box D for further discussion). 


\section{Box D \\ Operationalizing a Productivity-Oriented Portfolio}

Relative position in a productivity sense is measured on the horizontal axis in terms of Catalonia's labor productivity relative to the EU averages. The EU was selected as the reference group because of its dominance of Catalonia's international trade. While the productivity differential is measured here as a percentage of EU averages, one might also look at the differentials in absolute terms, or on some other basis that at least partially picks up on the idea that, for example, the level of value added per worker in wood is, because of low capital-intensity, etc., less than one-third of that in chemicals. Potential in productivity terms is measured on the vertical axis in terms of Catalonia's labor productivity growth rates. While one should ideally assess (and act upon) future productivity growth potential, BCG's use of historical growth as a proxy for future growth rates suggests the short-cut of using historical productivity growth rates in mapping Catalan industries. Historical growth rates are effectively compared across Catalan sectors rather than with some external reference group because there may be significant differences in productivity growth between Catalonia and other EU countries - as there have been, mostly in the form of Catalan shortfalls, in most recent years - yet Catalonia will likely end up having some industrial activity for a long time. Ranking Catalan industries relative to each other helps predict the likely mix.

Using Jaumandreu's data and redrawing the grid in these terms yields the representation in the next figure. What is perhaps most striking is the divergence in the positions of the automotive sector and food and beverages - in contrast to Torrens and Raluy's diagnosis of similarity. More broadly, significant international competitiveness problems seem to afflict all machinery and equipment sectors, not just automotive. Lighter manufacturing sectors have generally done better in terms of productivity growth, although Catalan productivity relative to EU averages varies. And some traditional sectors, such as textiles and food and beverages, have done well in terms of both relative productivity and productivity growth: as a former Catalan minister remarked to me, "focus on traditional sectors" was not a bad conclusion from the grid. In other words, high tech industries aren't intrinsically good and lower tech industries aren't intrinsically bad. And simply focusing on sectors with high technology content is not necessarily a recipe for maximizing productivity growth.

\section{Figure 11}

A productivity-Oriented Portfolio for Catalonia

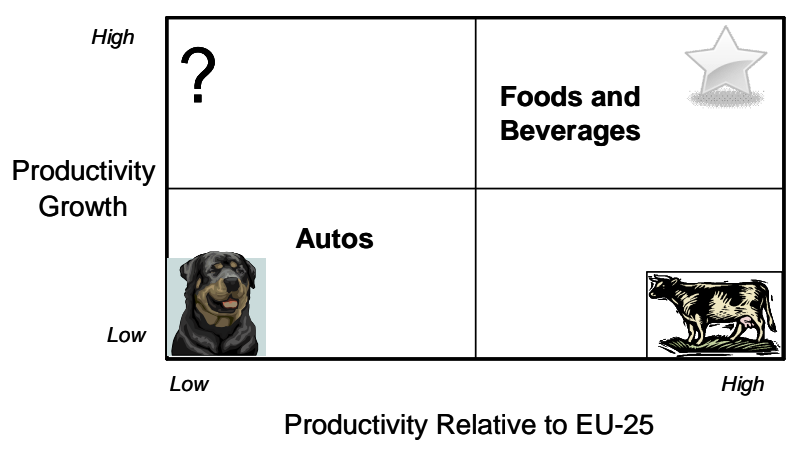


Corroboration of the usefulness of this way of positioning sector/industry portfolios is that they actually fit with revealed measures of external competitiveness. Interestingly, whether Catalonia has a productivity advantage over the rest of Spain turns out to be the best single predictor of its total external trade balance - the data for interregional and international trade balances reported in Section 1 - since interregional trade tends to be larger than international trade... which brings us to the topic of the next section.

\section{Internationalization-Related Implications}

One way of summarizing the broader implications of the foregoing for how policymakers should think of internationalization is that it is simple and economical of mental effort to dichotomize between local and global but also ineffective at generating new insights relative to the "single country" base case. If countries were completely isolated (the purely local case), strategy could be set country by country; and if they were completely integrated (the purely global case), the world would be one giant country and again, single-country strategy would suffice. Generating conceptually distinctive but grounded strategy content requires focusing on what lies between and, in some essential sense, beyond local and global: what Ghemawat (2003, 2007) characterizes as semiglobalization. The actual levels of cross-border integration today fall far from both zero integration and complete integration, implying that neither the bridges nor the barriers between countries can be ignored. And dealing with the challenges of semiglobalization as a linear combination of local and global approaches that are lazy in reaching beyond single-country strategy seems like a bad bet.

Some more specific implications of adopting a semi-global perspective follow:

1. Think regionally. Thinking regionally involves, in the first instance, paying attention to interregional (intranational) interactions as well as international ones. As discussed in Ghemawat, Llano and Requena, interregional flows fall through the cracks of local versus global when "local" refers to regions rather than nations - yet are comparable in magnitude to international flows in the Catalan case. As food and beverages illustrates, ignoring flows this large can lead to a fundamental misreading of external competitiveness. Other possible problems include missing key external relationships (Catalonia's largest is with Valencia), and marginalizing the periphery (Catalan provinces other than Barcelona depend more on interregional trade). In addition, estimated Catalan (international-to-interregional) border effects have declined since the 1990s but the declines appear to be flattening out, so interregional trade may play a bigger role in total growth in the future than it did between the mid-1990s and the mid-2000s.

Once one accepts the need to pay attention to interregional (intranational) interactions, there are a whole set of collateral implications, some of which are summarized in the table (which is organized in terms of the framework for thinking about differences that is developed under the next point). 


\section{Table 2}

Improving Interregional Integration: A Dozen Levers

\begin{tabular}{|c|c|c|c|}
\hline Cultural & Administrative & Geographical & Economic \\
\hline $\begin{array}{l}\text { Exploit language } \\
\text { bridges } \\
\text { Interregional } \\
\text { Networks/exchanges } \\
\text { students } \\
\text { Public relations efforts }\end{array}$ & $\begin{array}{l}\text { Harmonize: } \\
\text { - foreign invest. } \\
\text { promotion } \\
\text { - public buying } \\
\text { - health, safety, } \\
\text { environmental standards } \\
\text { Simplify cross-border } \\
\text { regulations and } \\
\text { paperwork } \\
\text { Bilateral/Multilateral } \\
\text { summits: } \\
\text { - share best practices in } \\
\text { government } \\
\text { - review general } \\
\text { institutions }\end{array}$ & $\begin{array}{l}\text { Improve regional } \\
\text { transportations/communi- } \\
\text { cations } \\
\text { Create an efficient } \\
\text { energy network } \\
\text { Coordinate infrastructural } \\
\text { investment }\end{array}$ & $\begin{array}{l}\text { Improve } \\
\text { interregional } \\
\text { linkages } \\
\text { - employee } \\
\text { mobility } \\
\text { - capital markets } \\
\text { - information } \\
\text { Exploit } \\
\text { scale/scope } \\
\text {-business } \\
\text { networks/events } \\
\text {-joint embassies } \\
\text {-process for } \\
\text { upgrading cross- } \\
\text { border clusters } \\
\text { Collect and } \\
\text { disseminate } \\
\text { information about } \\
\text { interregional flows }\end{array}$ \\
\hline
\end{tabular}

The second manifestation of regionalization is at the international rather than the national level: Nearly four-fifths of Catalonia's food and beverage international exports and two-thirds of its international imports are accounted for by trading partners within the EU, and the degree of regionalization of its auto trade is a bit higher still. While these numbers are higher than for other goods-producing Catalan sectors, about two-thirds of Catalan international trade, overall, is directed at the EU - consistent with the levels exhibited by other EU members. At the level of the world economy, one-half of international trade - and foreign direct investment as well occurs within regions, and regionalization tends to be lowest for the lowest-performing regions (e.g., Africa), suggesting that it shouldn't be seen as a "second-best" form of globalization. And at the firm level, even large firms in food and beverages and in autos that are present in multiple regions are described or describe themselves as following regionalized strategies.

2. Recognize differences - and differences in differences - across countries. The extent, persistence, and, in at least some instances, increasing regionalization of cross-border activity reflect the continuing importance of both geographic proximity and proximity along the other dimensions, primarily cultural and administrative, cited in the previous section to explain why the new Eastern members of the EU are, in several respects, closer to Germany than is Spain. These factors, about which the bar chart provides some more specifics, obviously intertwine: countries that are adjacent to each other are more likely to speak the same (or related) languages, and so on. So if the previous point argued for a comprehensive partitioning of space in terms of distance - with the objective, in part, of picking up on interregional flows that fall between the local and the global - this point is really highlighting both the multidimensionality of differences and differences in differences, i.e., the notion of countries being embedded in multidimensional space at varying distances from each other.

Ghemawat (2007) provides a roadmap for spotting the kinds of differences that matter for crossborder strategy, grouped into four kinds of "distance": Cultural, Administrative, Geographic, and 
Economic or, in shorthand, CAGE. Table 3 lists some of the elements of the CAGE framework at the country level:

\section{Table 3}

The CAGE "distances"

\begin{tabular}{|c|c|c|c|c|}
\hline & Cultural Distance & $\begin{array}{l}\text { Administrative } \\
\text { Distance }\end{array}$ & $\begin{array}{l}\text { Geographic } \\
\text { Distance }\end{array}$ & Economic Distance \\
\hline $\begin{array}{l}\text { Country Pairs } \\
\text { (Bilateral) }\end{array}$ & $\begin{array}{l}\text { Different } \\
\text { languages } \\
\text { Different } \\
\text { ethnicities; lack of } \\
\text { connective ethnic } \\
\text { or social networks } \\
\text { Different religions } \\
\text { Lack of trust } \\
\text { Different values, } \\
\text { norms, and } \\
\text { dispositions }\end{array}$ & $\begin{array}{l}\text { Lack of colonial ties } \\
\text { Lack of shared } \\
\text { regional trading bloc } \\
\text { Lack of common } \\
\text { currency } \\
\text { Political hostility }\end{array}$ & $\begin{array}{l}\text { Physical distance } \\
\text { Lack of land border } \\
\text { Differences in time } \\
\text { zones } \\
\text { Differences in } \\
\text { climates / disease } \\
\text { environments }\end{array}$ & $\begin{array}{l}\text { Rich/poor } \\
\text { differences } \\
\text { Other differences } \\
\text { in cost or quality of } \\
\text { natural resources, } \\
\text { financial } \\
\text { resources, human } \\
\text { resources, } \\
\text { infrastructure, } \\
\text { information or } \\
\text { knowledge }\end{array}$ \\
\hline $\begin{array}{l}\text { Countries } \\
\text { (Unilateral / } \\
\text { Multilateral) }\end{array}$ & $\begin{array}{l}\text { Insularity } \\
\text { Traditionalism }\end{array}$ & $\begin{array}{l}\text { Nonmarket/closed } \\
\text { economy (home bias } \\
\text { vs. foreign bias) } \\
\text { Lack of membership in } \\
\text { international } \\
\text { organizations } \\
\text { Weak institutions, } \\
\text { corruption }\end{array}$ & $\begin{array}{l}\text { Landlocked } \\
\text { Lack of internal } \\
\text { navigability } \\
\text { Geographic size } \\
\text { Geographic } \\
\text { remoteness } \\
\text { Weak } \\
\text { transportation or } \\
\text { communication } \\
\text { links }\end{array}$ & $\begin{array}{l}\text { Economic size } \\
\text { Low per capita } \\
\text { income }\end{array}$ \\
\hline
\end{tabular}

To understand why a sense of whether two countries are close or far apart from each other in such terms, consider the Mediterranean Initiative and particularly, variations in how close or far various countries along the Southern rim of the Mediterranean are from Catalonia/Spain. Morocco, for example, has less than 60\% of the GDP of Egypt but trades about three times as much with Spain as Egypt does - because Morocco is closer to Spain along geographic and other dimensions. And Spain is closer overall to Morocco than any other country on the Northern Rim of the Mediterranean except France, suggesting that Morocco is an attractive target for competitive as well as intrinsic reasons. It should be explicitly added that similar considerations also apply to foreign direct investment, which is why, for example, of the United States multinationals that operate in just one foreign country, 60\% are in Canada (and 10\% in the United Kingdom). Such consideration of what's close and what's far should be applied to questions about where to compete, but discussions with agencies of the Catalan government suggest that this is not, at present, being done. Thus, more than one business leader has asked whether Catalonia is doing enough to follow up on an early focus on Morocco - especially given how active smaller regions such as Castile and León have been there.

Of course, the impact of distance or difference varies markedly by industry. Thus, the geographic proximity between Spain and Morocco counts more in the cement industry than cultural factors, but the reverse is true for many "cultural goods." Or to think about the two sectors studied in this chapter, cultural differences tend to loom relatively large in the food and beverage sector, whereas administrative differences (standards, protectionism, etc.) and economic ones (differences in income/labor costs, and in fuel prices) in autos. To set strategy at the industry level, one typically has to start with the CAGE framework and ask which kinds of differences that it lists are 
particularly salient in the industry context being considered. The table below summarizes some of the attributes at the industry level that are likely to amplify the significance of distance along the different CAGE dimensions.

\section{Table 4}

Industry level factors that affect CAGE "distances"

\begin{tabular}{|c|c|c|c|}
\hline Cultural Distance & Administrative Distance & Geographic Distance & Economic Distance \\
\hline $\begin{array}{l}\text { Cultural differences } \\
\text { matter the most when: } \\
\text { Products have high } \\
\text { linguistic content (TV } \\
\text { programs) } \\
\text { Products matter to } \\
\text { cultural or national } \\
\text { identity (foods) } \\
\text { Product features vary in } \\
\text { terms of size (cars) or } \\
\text { standards (electrical } \\
\text { equipment) } \\
\text { Products carry country- } \\
\text { specific quality } \\
\text { associations (wines) }\end{array}$ & $\begin{array}{l}\text { Government } \\
\text { involvement is high in } \\
\text { industries that are: } \\
\text { Producers of staple } \\
\text { goods (electricity) } \\
\text { Producers of other } \\
\text { "entitlements" (drugs) } \\
\text { Large employers } \\
\text { (farming) } \\
\text { Large suppliers to } \\
\text { government (mass } \\
\text { transportation) } \\
\text { National champions } \\
\text { (aerospace) } \\
\text { Vital to national security } \\
\text { (telecommunications) } \\
\text { Exploiters of natural } \\
\text { resources (oil, mining) } \\
\text { Subject to high sunk } \\
\text { costs (infrastructure) }\end{array}$ & $\begin{array}{l}\text { Geography plays a } \\
\text { more important role } \\
\text { when: } \\
\text { Products have a low } \\
\text { value-to-weight or bulk } \\
\text { ratio (cement) } \\
\text { Products are fragile or } \\
\text { perishable (glass, fruit) } \\
\text { Local supervision and } \\
\text { operational } \\
\text { requirements are high } \\
\text { (services) }\end{array}$ & $\begin{array}{l}\text { Economic differences } \\
\text { matter the biggest } \\
\text { impact when: } \\
\text { Nature of demand } \\
\text { varies with income } \\
\text { (cars) } \\
\text { Economics of } \\
\text { standardization or scale } \\
\text { are limited (cement) } \\
\text { Labor and other factor } \\
\text { cost differences are } \\
\text { salient (garments) } \\
\text { Distribution or business } \\
\text { systems are different } \\
\text { (insurance) } \\
\text { Companies need to be } \\
\text { responsive and agile } \\
\text { (home appliances) }\end{array}$ \\
\hline
\end{tabular}

3. Respond creatively to differences. Facing the broad range of cross-country differences an international strategy must address, one might be tempted to throw up one's hands and take one of the easy ways out: compete the same way everywhere or delegate full authority to country managers to adjust each local operation to its unique conditions. But that would be a mistake. There is a rich menu of strategic options from which to craft competitively distinctive strategies that address cross-country differences. Ghemawat (2007) groups them into three categories: adaptation to adjust to differences and achieve local responsiveness, aggregation to overcome differences and achieve cross-border economies of scale/scope, and arbitrage to exploit differences and achieve absolute (rather than scale-based) economies.

\section{Figure 12}

Strategies that address cross-country differences

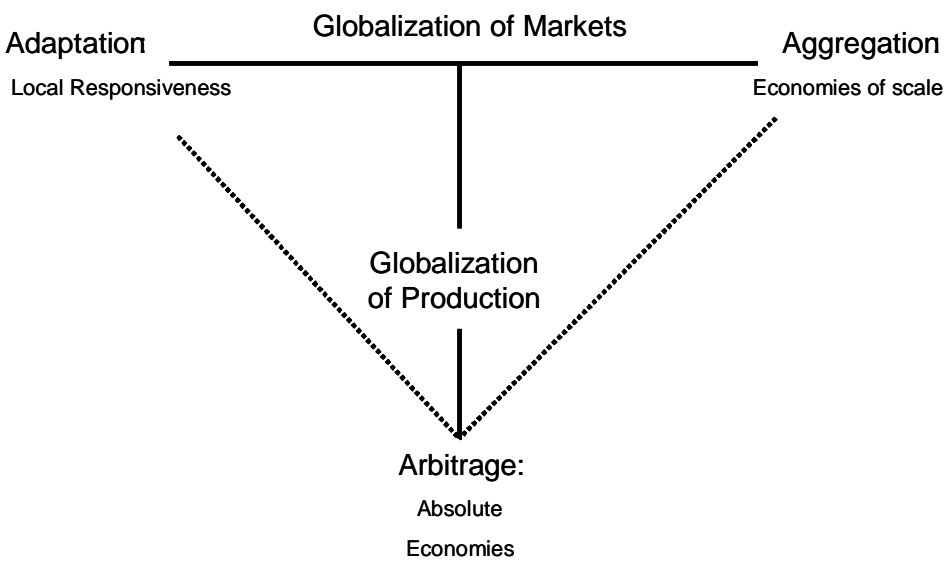


This typology of $A A A$ strategies for dealing with differences can be used to contrast internationalization in the two sectors. High border effects mean that international food and beverage companies must pay great attention to adaptation to national differences, whereas country-specific adaptation is less common in autos. Strategies of regional aggregation are evident in both sectors - in food and beverages, mostly through focus on a single region, and in autos because of global automakers' regional hubs. The impulse towards aggregation also shows up in the drive to build up intangible knowhow and other assets - typically more related to marketing in food and beverages and to technology or operations in autos - that are subject to increasing returns to scale. And finally, (economic) arbitrage by competitors in low cost countries is a threat to both sectors, but less so in less-internationalized food and beverages, which also affords (cultural) arbitrage advantages based on local origins.

From a public policy perspective, the need for adaptation complicates the easy image of firms coming up with product innovations and then exporting them: product and other requirements vary - in multitudinous ways and to different extents - across countries, as discussed above. There are obvious advantages to anticipating such differences instead of simply stumbling over them. Other recommendations in this regard, based on studies of small business internationalization in other countries (e.g., "Costs of Developing a Foreign Market for a Small Business: The Market \& Non-Market Barriers to Exporting by Small Firms," Palmetto Consulting for the United States Small Business Administration, November 2004), include:

- Encouraging and facilitating exploration of international markets, since many firms tend to be reactive rather than proactive in internationalizing and, even after they have begun to export, operate with limited market information.

- Being realistic about the time, travel, financing and other resource requirements of serving foreign markets in order to avoid stop-go-stop export behavior.

- Focusing basic remediation on small firms since, according to Cassiman and Golovko; $90 \%+$ of Catalan firms with more than 100 employees are exporters or importers. Larger firms' needs tend to be more specialized and idiosyncratic.

In terms of aggregation, one obvious governmental role is to help small firms, in particular, exploit scale economies through cooperative activities such as trade fairs, business missions, etc. And to focus on geographic regions, while internationally-experienced Catalan firms have already discovered the gravitational pull of the EU, the extent of regionalization of cross-border strategy is still a surprise to many inexperienced firms and therefore helpful to recap in the context of their market selection decisions. And, looking forward, Catalonia has the challenge of defining, within the context of the overall Spanish approach, its strategy towards the Southern rim of the Mediterranean in particular as well as a potential hub for the whole Mediterranean region. South/East Asia is another region that could presumably benefit from an integrated perspective as well as country-by-country analysis.

The third of the AAA strategies, arbitrage, is often anathema to public policymakers, who associate it with job losses to countries with cheaper labor. But the observations that arbitrage was the original strategy that firms applied to cross-border trade and commerce, and that it is still evident in Catalonia's role as import hub for Spain, suggest that it isn't all bad. Lowering costs is a direct way to increase effective factor productivity - also see the next point in this regard. The example of geographic indications in food suggests that arbitrage can also have a noneconomic basis, that it can affect willingness-to-pay as well as costs, and that the scope for some kinds of arbitrage are actually increasing rather than decreasing. And the example of auto 
engineering offshoring reminds us that arbitrage is no longer confined to low-end activities, or to physical products. The bottom line: most firms need to think about arbitrage, even if it isn't their targeted basis for cross-border advantage, to ensure that their relative economics, and especially costs, do not get too far out of line with competitors'. And this point may need particular emphasis in a context that originally was relatively low cost but has lost that position - without quite adjusting to that reality.

4. Resist the obsession with producing at home and selling globally. As noted earlier, the typical regional competitiveness study, borrowing a page from national competitiveness studies, tends to focus on international flows to the exclusion of interregional flows that are often as large or larger - and that can change analyses of external competitiveness. The common, neomercantilistic objective function of producing at home and selling around the world has several other problems associated with it as well.

First, neomercantilism encourages exports and discourages exports. Yet the input-output tables suggest that, internationally and interregionally, imports have been critical to Catalan exports in both food and beverages and autos. More generally, Cassiman and Golovko highlight the limitations of the focus on exports with their careful attempt to unpack the relationship between productivity and exports by taking a firm-level look at factors that might be an antecedent to both. In a panel of Catalan firms, they find that imports actually seem to have more to do with innovativeness and productivity than with exports. This is consistent with Catalonia being, along with Madrid, a major import hub for Spain. And in terms of inbound foreign direct investment (FDI), it is worth remembering that, in both food and beverages and autos, multinationals from overseas that have invested in Catalonia have not only brought in capital and created jobs but have also led to identifiable spillovers of management techniques and practices to local firms - which is not to say that more couldn't be done to boost the level of spillovers.

Second, to dig deeper into FDI, the neomercantilistic approach does not have anything very definite to say about two key policy questions: on inbound FDI, whether foreign-owned operations in Catalonia are exactly the same as locally-owned ones, and on outbound FDI, how, if at all to encourage the expansion of multinationals from Catalonia. While not having space to discuss these questions at length, it is worth noting some of the differences between foreignowned firms and local ones. Thus, in the auto sector, Volkswagen shut down a plant in Belgium even though it was alleged that it would have made more economic sense to reduce capacity in Germany instead. In addition to home-bias, domestically owned firms are likely to engender greater/broader spillover effects, be more committed to a country/region as a theatre of operations and, it must be said, be more amenable to local governmental 'clout'. At the same time, multinationals from overseas have their roles to play as well in setting up in Catalonia, as sources of additional competition as well as carriers of intangibles such as brands, technology and expertise. But one does not have to diminish either group of competitors to recognize some difference in average tendencies.

Some of the same differences between locally-owned and foreign-owned firms underlie Catalan policymakers' interest in building up locally-headquartered multinationals. This again is a topic that is too vast to be covered here, but at least two competitive challenges must be mentioned. For one thing, even large local firms are late-movers in moving overseas, and confront entrenched multinational competitors within generally stagnant markets in Western Europe and other advanced regions - a prospect that has even forced some to focus on unfashionable parts of the world, e.g., Gallina Blanca's dominance of West Africa with its Jumbo stock cubes. In 
addition, they must also contend with firms from other parts of Spain looking to climb the same ladder. e.g., Aceites Borges being beaten by SOS Cuétara in the acquisition of Italian olive oil leader Bertolli. And in autos, nobody is seriously suggesting that the Catalan government help form a new, locally based OEM, so the Catalan cluster is likely to be partial rather than complete in a few years and to that extent, even more dependent on inflows for its competitiveness.

A third problem with the idea of producing at home for sale around the world is that it embodies an extreme dichotomization of the effects of distance: it assumes that, on the production side, geographic distance is prohibitive in the sense that all "interesting" interactions are localized, but that in going to market (as well as in "uninteresting" interactions), distance is no deterrent. ${ }^{10}$ Thus, Michael Porter's HBR article on Clusters and the New Economics of Competition begins as follows:

"Paradoxically, the enduring competitive advantages in a global economy lie increasingly in local things - knowledge, relationships, and motivation that distant rivals cannot match... now that companies can source capital, goods, information, and technology from around the world, often with the click of a mouse."

This chapter has suggested that, instead of bucketing economic interactions into local versus global (based on whether distance effects are very high or very low), it makes sense to take a more stretched out look at distance and its effects as a way of moving beyond the binary contrast of home versus abroad towards an understanding of degrees of cross-border difference. This conception of distance and its effects encompasses local and global as extreme possibilities - and helps with the handling of the more complex cases of intermediate distance effects. While it isn't always feasible, let alone desirable, to localize supply entirely (as the case of autos illustrated), the CAGE distance framework, along with the AAA strategy archetypes, can be used for help with input sourcing decisions. On the demand side, since ubiquity is rarely the right target, the framework helps with the prioritization of markets as well. And also note that getting away from the assumptions of (complete) factor immobility and product mobility relaxes the mostly unrealistic presumption of "one best location" worldwide.

To summarize, what is needed is not a mentality of producing at home to sell worldwide but rather, an approach that is open in a more general sense: an approach that looks outside the home base for inputs, markets and ideas. The advantages in terms of cheaper/better inputs and expanded markets are obvious. In the specific context of ideas, considerable attention has been captured recently by open innovation. Openness also helps with the other productivity enhancement mechanisms discussed above, particularly replication, replacement and redeployment. And, furthermore, it also has deep roots in Catalan history. For all these reasons, it comes close to being a touchstone for all policy decisions about internationalization. And government probably also has a transactional role to play in encouraging cross-border interactions at levels ranging from the corporate or (other) institutional down to individual connectivity and networking.

\footnotetext{
${ }^{10}$ Porter does, however, argue that feedback effects from product markets are highly localized, so product markets are imperfectly rather than perfectly integrated from that perspective. But otherwise, the emphasis falls on the quest for global leadership, maybe within a segment, rather than product market impediments that might get in the way.
} 


\section{Conclusions}

This chapter began by looking at interregional as well as international trade by sector, which shifted inferences about which Catalan sectors are externally competitive (proxied by trade surpluses) and highlighted significant cross-sector variation in border effects. To dig deeper into the determinants of productivity and the role of internationalization, it focused in on two large sectors, food and beverages (relatively high border effects) and autos (relatively low border effects).

Food and beverages has enjoyed substantially faster productivity growth than autos, affording Catalonia a productivity advantage relative to the EU-25 averages and generating substantial external surpluses for it (thanks to interregional trade surpluses that offset international deficits). Since food and beverages is considered to be lower tech and to afford less room for innovation than autos, this naturally raised questions about mechanisms for productivity growth other than innovation. The sectoral studies, in addition to broadening conceptions of innovation beyond science-based product innovation, suggested a host of productivity enhancement mechanisms involving renovation rather than innovation - reaching scale, rectification, replication, replacement and redeployment - and called attention to the role of the demand side as well as the supply side.

In relation to internationalization, both food and beverages were, despite exhibiting very different levels of border effects, subject to similar pressures as a result of semiglobalization and led to similar implications: think regionally, understand differences in the degree to which other regions/countries differ from Catalonia, think creatively about responses to differences and, instead of the neomercantilistic fantasy of producing at home to sell to the world, stress openness on the inbound side as well as the outbound. 


\section{References}

Avermaete, T., J. Viaene, E.J. Morgan, E. Pitts, N. Crawford, and D. Mahon (2004), "Determinants of product and process innovation in small food manufacturing firms," Trends in Food Science and Technology, 15, pp. 474-483.

Becker, H. (2006), “High Noon in the Automotive Industry,” Springer, 2006.

Bellezza, S. (2008), "Food Processing in Catalonia. Industry Analysis."

Casadesus-Masanell, R., and J.E. Ricart (2009), "Company Strategy: Business Model Reconfiguration for Innovation and Internationalization.”

Camacho-Cabiscol, J-M., R. Alemany-Leira, and J. Baró-Llinàs, “Job Flows in Catalonia.” Paper presented at th $40^{\text {th }}$ European Congress of the European Regional Science Association, Barcelona, $30^{\text {th }}$ August- $2^{\text {nd }}$ September, 2000.

Cassiman, B., and E. Golovko (2008), "Productivity of Catalan Firms. International Exposure and (Product) Innovation."

Caves, R., and M. Uekusa (1976), "Industrial Organization in Japan," Washington: Brookings Institute.

Cazorla, V. (2008), "Industry Study: Automotive Sector in Catalonia."

“Gardiner \& Theobald Survey,” December 2003.

Ghemawat, P. (2003), "TUSemiglobalization and International Business StrategyUT," Journal of International Business Studies, 34, No. 2, pp. 138-152.

Ghemawat, P. (2001), "Distance Still Matters: The Hard Reality of Global Expansion," Harvard Business Review, 79, No. 8, pp. 137-147.

Ghemawat, P., and R. Malik (2003), "The Industry-Level Structure of International Trade Networks: A Gravity-Based Approach,” Working Paper.

Ghemawat, P., C. Llano, and F. Requena (2009), "Rethinking Regional Competitiveness: Catalonia's International and Interregional Trade, 1995-2006.”

"Innovation in Catalonia" (2006), Cidem, Study Collection, p. 173.

McKinsey \& Company (2004), "Fostering Excellence: Challenges for Productivity Growth in Europe," background document prepared for the Netherlands' Ministry of Economic Affairs for the Informal Competitiveness Council, Maastrich, July 1-3.

Palmetto Consulting (2004), "Costs of Developing a Foreign Market for a Small Business: The Market \& Nonmarket Barriers to Exporting by Small Firms,” November.

Torrens, L. and M. Raluy (2008), “L'atracció de la inversió directa estrangera a Catalunya.” 